Research

\title{
Delineating springs safeguard zones with DISCO-URBAN index: a valuable tool for groundwater vulnerability mapping in local-scale urban areas
}

\author{
Helen Meerkhan ${ }^{1,3} \cdot$ Liliana Freitas $^{1,3} \cdot$ Alcides J. S. C. Pereira ${ }^{2} \cdot$ Fernando Rocha $^{3} \cdot$ Helder I. Chaminé $^{1,3}$ (ID \\ Received: 21 December 2021 / Accepted: 17 February 2022 \\ Published online: 01 March 2022 \\ (c) The Author(s) 2022 OPEN
}

\begin{abstract}
Assessing groundwater vulnerability to contamination is vital worldwide, particularly in sustainable water resources management. That is mainly a concern in fractured media in urban areas due to a large diversity of contaminant sources and the complexity of recharge pathways. Thus, groundwater vulnerability assessment is essential to delineate groundwater protection zones around springs or wellheads. Furthermore, it considers the groundwater system's heterogeneity and the surrounding hydrogeological conditions, as well as provides suitable solutions to protect the resource and mitigate potential hazards. DISCO-URBAN index focused on urban areas was applied to evaluate the intrinsic vulnerability in fractured media in the surroundings of Penafiel city (NW Portugal). The analytic hierarchy process (AHP) was used to determine the weight of each evaluation factor. Furthermore, multi-criteria indexes were applied: GOD-S, DRASTIC-Fm, SI DISCO and DISCO-URBAN. Low to moderate vulnerability classes dominate in the combined approach of the vulnerability indexes. However, very high vulnerability classes occur in DISCO and DISCO-URBAN, corroborated by the waterenriched nitrates. Therefore, the DISCO-URBAN method highlights a better delineation of groundwater safeguard zones. In fact, the DISCO-URBAN index is reliable in urban areas to be integrated as a tool to develop local site hydrogeological investigations related to springs safeguard zones.
\end{abstract}

Keywords Urban groundwater · Vulnerability · Sustainability · GIS mapping · Geovisualisation techniques

\section{Introduction}

Urbanisation shifts topography, vegetation, stream flows, and flooding characteristics, affecting groundwater quantity and quality. The groundwater systems in urban areas can provide an excellent potential source for multi-purposes, including irrigation of green areas. Therefore, it is necessary to evaluate groundwater vulnerability to contamination in fractured media to be integrated as a tool for urban planning and the sustainable management of groundwater resources in urban areas (e.g., [1-6]).

Supplementary Information The online version contains supplementary material available at https://doi.org/10.1007/s43832-02200011-z.

$\triangle$ Helder I. Chaminé, hic@isep.ipp.pt | 1 Department of Geotechnical Engineering, Laboratory of Cartography and Applied Geology (LABCARGA), School of Engineering (ISEP), Polytechnic of Porto, Porto, Portugal. ${ }^{2}$ Department of Earth Sciences, Centre CITEUC, Faculty of Sciences, University of Coimbra, Coimbra, Portugal. ${ }^{3}$ Department of Geosciences, Centre GeoBioTec, University of Aveiro, Aveiro, Portugal.

Discover Water $\quad$ (2022) 2:2 |https://doi.org/10.1007/s43832-022-00011-z 
The urban hydrogeological comprehensive studies are necessary to manage the interface and the interactions between surface and groundwater systems (e.g., [4, 7-15]). The first consequence of urbanisation around the catchments is the impervious cover of the ground (e.g., [16-18]). However, the vegetal zones mitigate the imperviousness effect. Nevertheless, there are changes in groundwater systems in recharge, piezometric levels, streamflow regime, and surface and groundwater quality hazards due to urban growth. Furthermore, urban infrastructure modifies interflow by creating barriers and preferential runoff zones, sinkholes, geotechnical issues, and new recharge water sources from public supply and sanitation networks (e.g., $[1,4,7,11,13,14,16-23])$. Therefore, it makes perfect sense to integrate the principles of urban hydrogeosciences into the concerns of integrated groundwater systems management to preserve qualitative and quantitative sustainable water resources. Thus, several authors underlined the importance of comprehensive studies on nature-based solutions for groundwater resources in urban contexts, such as springs and water mines (e.g., [24, 25]). Also, rural hydrogeology in peri-urban areas is a topical field to support local communities and design sustainable water resources management (e.g., $[5,12,26])$.

The vulnerability of groundwater systems is related to the sensitivity of groundwater to an imposed contaminant load and the possibility of diffusion and/or filtration of pollutants from the land's surface into water table reservoirs under normal conditions (e.g., $[1,7,27-31])$. Therefore, evaluating groundwater vulnerability to contamination is essential to delineating potential contamination in urban areas (e.g., [10, 11, 19, 32-37]). Several authors highlighted the importance of assessing groundwater vulnerability to contamination to identify zones with high contamination hazards or risk to assess the possibility of aquifer contamination (e.g., [27, 28, 30, 34]). Groundwater vulnerability assessments are usually represented through maps displaying zones where the resource is vulnerable to contamination from several sources. Vulnerability mapping is a suitable technique for assessing hydrogeological factors, among others, with the groundwater for potential contamination in a specific region shown on a map. Displaying zones in different colours is an easy and intuitive way to classify, distinguish and interpret groundwater vulnerability, and it can also be used for delineating protection zones (e.g., [10, 11, 13, 14, 30], and references therein). It is possible to delineate protection zones from the vulnerability and assess groundwater vulnerability using several methods. Typical intrinsic vulnerability indexes in fissured media, with different scale approaches, are: DRASTIC-Fm, GOD-S, SI, DISCO, DISCO-URBAN, among others (e.g., [34, 37-47], and references therein). Meerkhan et al. [37] highlighted that DISCO-URBAN is a reliable method for local investigations to delineate groundwater protection areas (springs, wellheads), high-resolution vulnerability mapping and support groundwater management activities in urban areas.

The Geographic Information System (GIS) based mapping approach provides an accurate approach for assessing groundwater vulnerability to contamination. In addition, index and overlay methods are the most suitable methods for groundwater vulnerability assessment (e.g., [8, 28,48-51]). Delineating the hydrogeological conceptual site model is of greater interest on the correct understanding of functioning groundwater systems in a changing society, environment, and climate (e.g., [50, 52]).

This study aims to present an original study on a local scale-site (Penafiel urban area, NW Portugal), focused on the importance of the DISCO-URBAN methodology to delineate groundwater safeguard zones around springs galleries and a high-resolution vulnerability protection mapping based on GIS-based mapping and geovisualisation techniques. Besides, an index-overlay method such as DRASTIC-Fm, GOD-S, SI was also employed to assess the groundwater vulnerability. The results of groundwater vulnerability mapping obtained from these methods will be compared with the DISCO-URBAN result, identifying which method is most accurate and reliable for delineating groundwater safeguard zones in the study area. That also aims to contribute to the definition of the site hydrogeological conceptual model.

\section{Background of the area: Santa Marta springs}

The study area is in Penafiel municipality in NW Portugal. This municipality has $22.5 \mathrm{~km}^{2}$ with 15,700 inhabitants [53], corresponding to a low population density ( 697 people $/ \mathrm{km}^{2}$ ). Figure 1 shows the geographical, geological, and hydroclimatological settings of the study site in the surroundings of the Penafiel municipality, NW Portugal. The Santa Marta springs are located in the NE part of the Penafiel municipality, mainly built in the urban fabric. A length underground gallery mines dug in rock media access Santa Marta springs.

The bedrock of the Penafiel is constituted by granitic rocks (fissured media), especially porphyritic two-mica coarse-grained granite, wide to moderate fracturing, slight to moderate weathered, and very low to low permeability (Fig. 1b, Table 1). The crystalline bedrock is outcropped by dolerite dykes and sedimentary cover (alluvia), related to 
Fig. 1 Location of Santa Marta springs and underground water mine, Penafiel urban area (NW Portugal): a a general background and hydrogeological inventory; b local geological setting; c land use framework; d climatology features

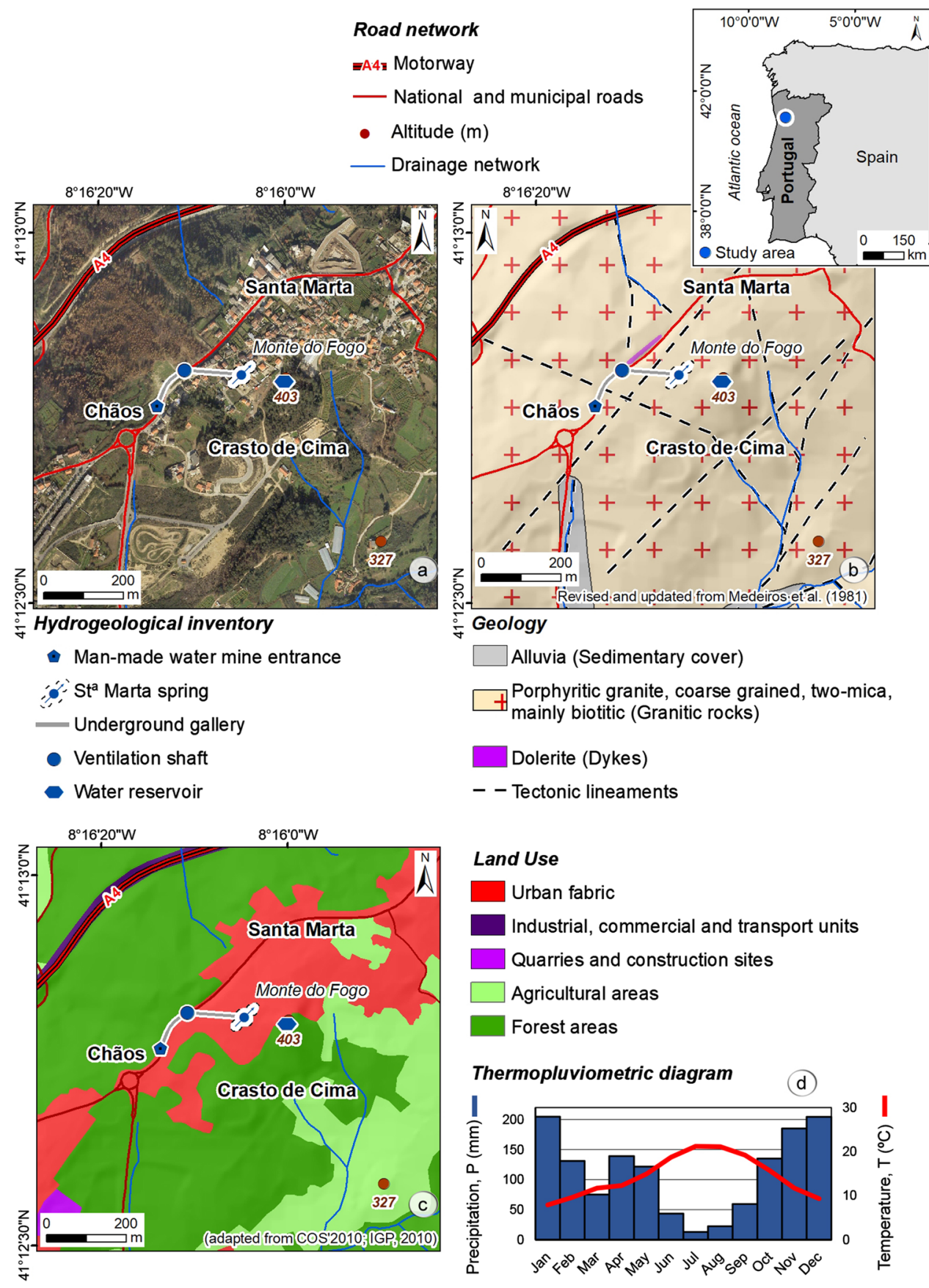

some streams [54]. Figure 1c presents the land use map of the study area, showing that forest areas are predominant (59\%), followed by urban areas (22\%) and agricultural areas (17\%).

The local climatic and hydrological conditions significantly impact the regional flows supplied to irrigate green spaces in the Penafiel urban area. Based on the climate series from the Portuguese Water Resources Information System (SNIRH), the climate in the Penafiel urban area is moderate, having an Atlantic influence. According to the Köppen classification [55], Penafiel has a Mediterranean climate (Csb) with hot and dry summer months. The average annual temperature is $14{ }^{\circ} \mathrm{C}$, ranging from $8{ }^{\circ} \mathrm{C}$ in January to $21^{\circ} \mathrm{C}$ in July. The average annual rainfall is $1335 \mathrm{~mm}$. The average monthly precipitation reaches more than $150 \mathrm{~mm}$ between November and March (the wettest months) and less than $30 \mathrm{~mm}$ in July and August (the driest months) (Fig. 1d). 


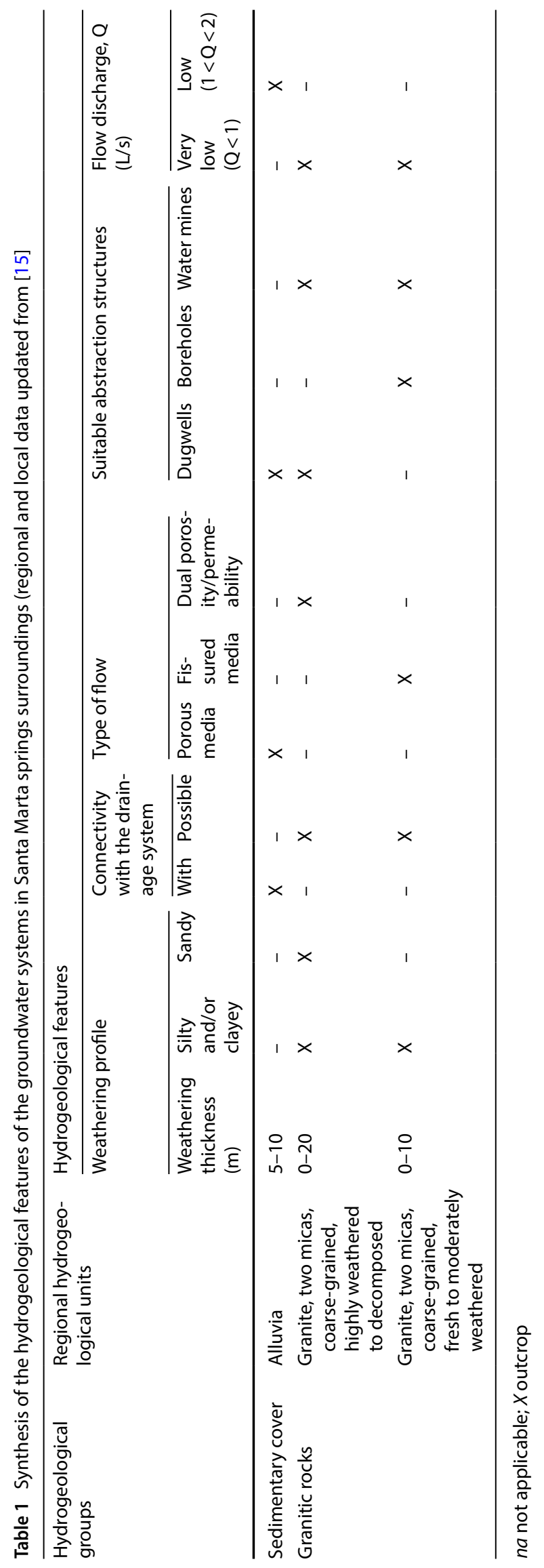


Figure 2 presents the Santa Marta water mine setting, which can be crucial for water supply to the main green spaces and public fountains in the urban area of Penafiel (Fig. 2a). The area's groundwater flow is related to the Santa Marta springs $[15,49]$. The Santa Marta springs are located at about $380 \mathrm{~m}$, close to the water deposit of the Municipality of Penafiel, namely in a hillslope "Monte do Fogo" site. The underground galleries mainly trend an E-W orientation, then inflect to NNE-SSW. Historical and current data related to the springer flow was collected to assess the potential of groundwater sustainability (Fig. 2a, b). The measured flow in the summer at the Santa Marta mine is close to the recorded historical values, i.e., about $0.40 \mathrm{~L} / \mathrm{s}$ (details in [15]).

The regional geomorphology and geotectonic framework is part of the Central-Iberian Zone (ZCI) of the Iberian Massif [56]. Locally, the study area is located in dominant tectonic lineaments towards NE-SW, mainly in the flattened area (Santa Marta) (Fig. 2C). That will be responsible for the regional arrangement of the relief in this region, where the entire urban area of Penafiel develops.

Moreover, the drainage network refers to this tectonic control, which gives the area morphostructural features. The mine's entrance is at the height of $352 \mathrm{~m} \mathrm{(Fig.} \mathrm{2c)} \mathrm{and} \mathrm{should} \mathrm{be} \mathrm{found,} \mathrm{entirely} \mathrm{excavated} \mathrm{in} \mathrm{granitic} \mathrm{rocks,} \mathrm{namely} \mathrm{in}$ the porphyritic granite, coarse-grained, slightly to moderate weathered $\left(\mathrm{W}_{2}-\mathrm{W}_{3}\right)$ (Fig. 2e). The principal fracture network highlights the following directions: NE-SW, NNW-SSE, and ENE-WSW. In addition, at the local scale, outcrops quartz veins

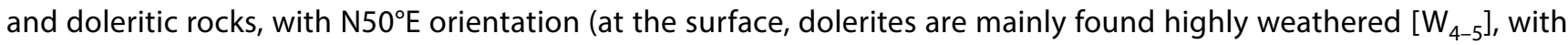
orangey colour).

\section{Materials and methods}

To achieve a comprehensive analysis and conceptualisation of the Santa Marta springs (Penafiel urban area, NW Portugal), a multidisciplinary approach using field and laboratory techniques were performed to access urban groundwater vulnerability to contamination and delineate safeguard zones in urban areas (Fig. 3). Using a GIS-based mapping, a collection of several urban data was successfully organised, namely geology, hydrogeology, hydrogeomorphology, land use/cover, and urban hydraulics and sanitation. Also, GIS overlay techniques were used to integrate and analyse the urban geodatabases and produce all thematic maps [50,52] and geovisualisation techniques [57]. As a result, the mapmaking procedures and design and the conceptualisation of maps have developed immensely. Furthermore, new trends exploring geovisualisation analysis integrate approaches from different disciplines, including scientific visualisation, image analysis, information visualisation, exploratory data analysis and GIS science (e.g., [50, 57]). According to Kraak [58], geovisualisation combines the strength of the computer (automated analysis techniques and geo-computation) and the human (interactive visualisations for adequate understanding, reasoning and decision making).

Portugal land use/cover map (COS 2018) was used to define the land use and cover of the urban study area. Furthermore, to improve the high-resolution mapping and maintain the base structure of the COS2018, it was cross-checked and updated using Maxar satellite imagery ( $0.5 \mathrm{~m}$ resolution, available through the ArcGIS base map service) and fieldwork, following the guidelines suggested by [59]. Additionally, the inventory of potential contamination activities was mapped from extensive PhD research surveys during 2014-2021 [60, 61]. The geology map background was revised from the Portuguese Geological Survey and was updated during the fieldwork. The hydrogeotechnical surveys have followed the recommendations of the [62].

Moreover, a multi-scale urban groundwater vulnerability to contamination assessment in the Santa Marta water springs was delineated based on comparison and integration of three indexes to reach more accurate results, namely GOD-S [27, 41] DRASTIC-Fm [42], SI [46]. The previous indexes are significant for regional to local purposes. The data was processed, and the indexes were calculated using raster format and overlay tools in the GIS environment. The information that served as a basis for the vulnerability assessment corresponds to the hydrogeological background. The overlay analysis was made by converting each layer into a raster of $4 \times 4 \mathrm{~m}\left(16 \mathrm{~m}^{2}\right)$. The international colour code for DRASTIC was applied to the vulnerability representation.

DISCO index [30, 43,63] and DISCO-URBAN index [37] were calculated to delineate groundwater protection zones mapping around the Santa Marta springs and underground water mine site. The DISCO method has successfully proven its ability to assess groundwater's vulnerability to contamination, especially in highly heterogeneous fractured aquifers, by its dependence on DIScontinuities and protective COver parameters (e.g., [30, 43]). Conversely, the DISCO-URBAN index is a new approach developed for urban areas with an excellent asset for local-scale investigations [37]. Table 2 shows the strengths and weaknesses of the groundwater vulnerability indexes in fissured rock media focused on urban areas. 


\begin{tabular}{|c|c|c|}
\hline \multirow{2}{*}{ Year } & \multirow{2}{*}{ Date } & Flow (L/s) \\
\hline & & $\mathrm{St}^{\mathrm{t}}$ Marta water mine \\
\hline \multirow{2}{*}{1937} & $24 / 10 / 1937$ & 0,20 \\
\hline & $22 / 12 / 1937$ & 2,27 \\
\hline \multirow{4}{*}{1938} & $28 / 02 / 1938$ & 2,50 \\
\hline & $27 / 05 / 1938$ & 0,22 \\
\hline & $24 / 09 / 1938$ & 0,09 \\
\hline & $28 / 11 / 1938$ & 0,13 \\
\hline \multirow{5}{*}{1939} & $25 / 01 / 1939$ & 1,00 \\
\hline & 29/04/1939 & 1,25 \\
\hline & $28 / 06 / 1939$ & 0,42 \\
\hline & $27 / 08 / 1939$ & 0,21 \\
\hline & $30 / 10 / 1939$ & 1,14 \\
\hline \multirow{5}{*}{1940} & $09 / 01 / 1940$ & 1,19 \\
\hline & $09 / 04 / 1940$ & 0,89 \\
\hline & $21 / 08 / 1940$ & 0,25 \\
\hline & $14 / 10 / 1940$ & 0,11 \\
\hline & $16 / 11 / 1940$ & 0,81 \\
\hline \multirow{5}{*}{1941} & $11 / 01 / 1941$ & 1,32 \\
\hline & $17 / 03 / 1941$ & 2,27 \\
\hline & $14 / 06 / 1941$ & 0,69 \\
\hline & 13/09/1941 & 0,52 \\
\hline & $19 / 11 / 1941$ & 0,10 \\
\hline \multirow{4}{*}{1942} & $16 / 03 / 1942$ & 1,47 \\
\hline & $23 / 06 / 1942$ & 0,83 \\
\hline & $21 / 08 / 1942$ & 0,13 \\
\hline & $11 / 11 / 1942$ & 0,11 \\
\hline \multirow{2}{*}{2020} & $19 / 06 / 2020$ & 0,39 \\
\hline & $16 / 09 / 2020$ & 0,26 \\
\hline
\end{tabular}

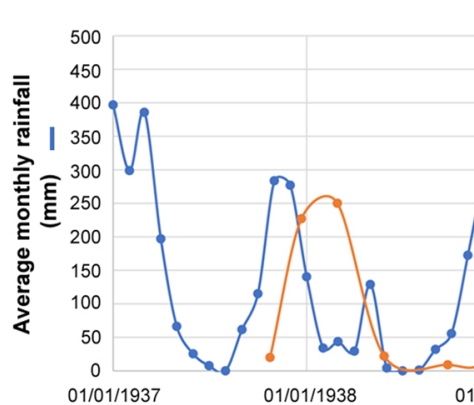

(c)

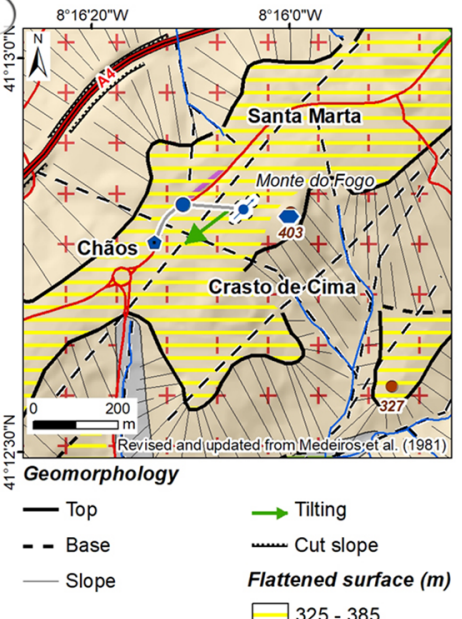

Geology

$\square$ Alluvia (Sedimentary cover)

Porphyritic granite, coarse grained, two-mica, mainly biotitic (Granitic rocks)

Dolerite (Dykes)

- - Tectonic lineaments

- Altitude (m)

- Drainage network

Hydrogeological inventory

- Man-made water mine entrance

- Ventilation shaft

- Underground gallery Water reservoir

- Underground gallery Water reservoir
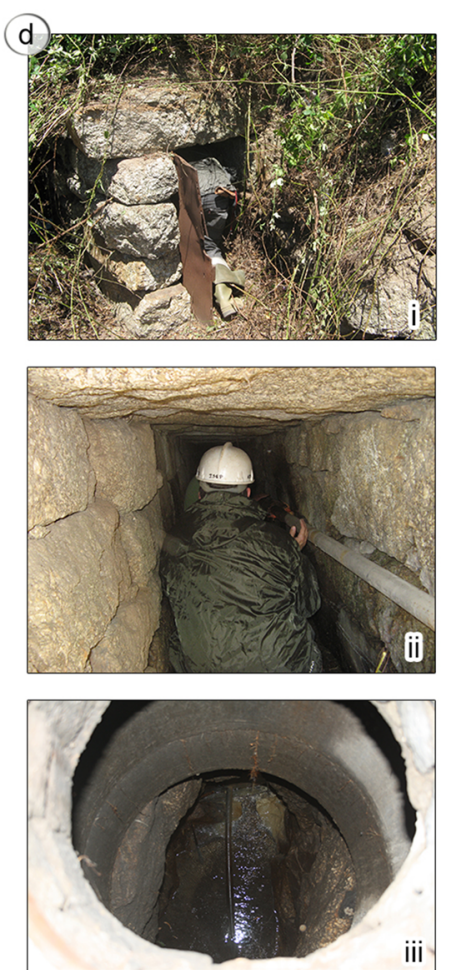

(b) ${ }^{5}$

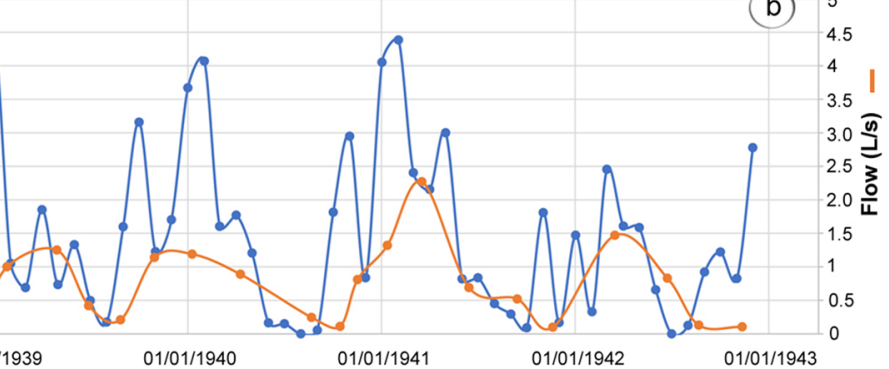

$01 / 01 / 1939$

01/01/1940

01/01/1941

01/01/1943

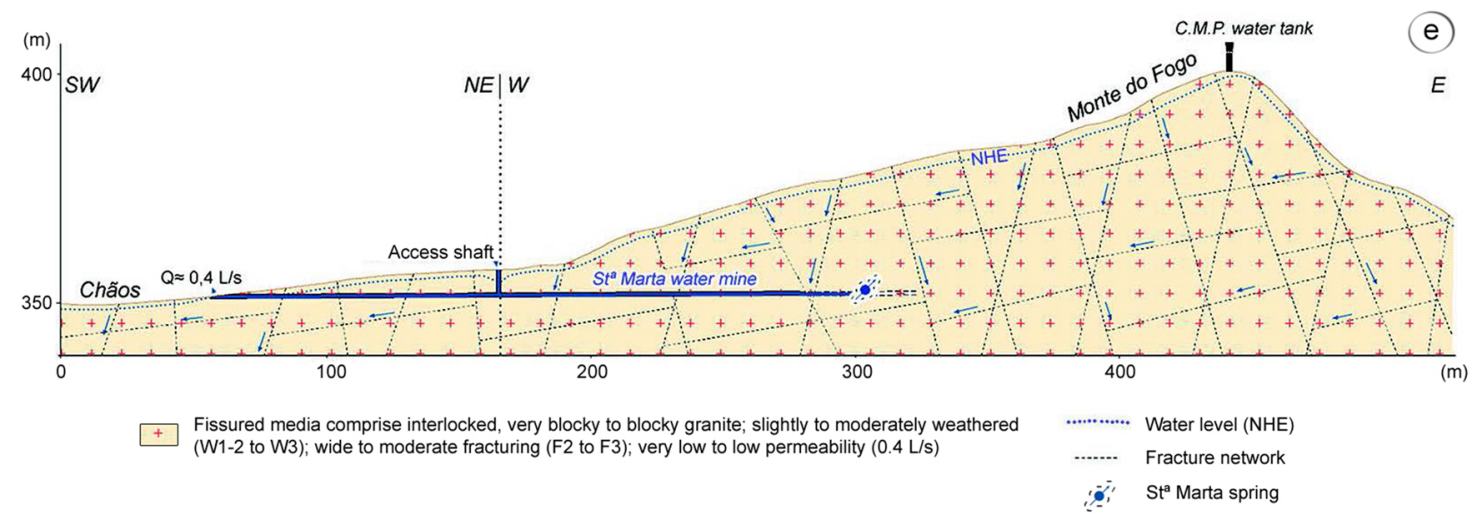

Fig. 2 Santa Marta water mine (Penafiel urban area, NW Portugal): a historical and current data related to groundwater flow; $\mathbf{b}$ evolution of rainfall vs spring discharge based on historical hydrological data (1937-1942); rainfall data after https://snirh.apambiente.pt and flow discharge from Penafiel Municipality; $\mathbf{c}$ geomorphological setting; $\mathbf{d}$ aspects of the man-made water mine (i-entrance; ii-gallery; iii-access shaft); e hydrogeological cross-section of the study area 


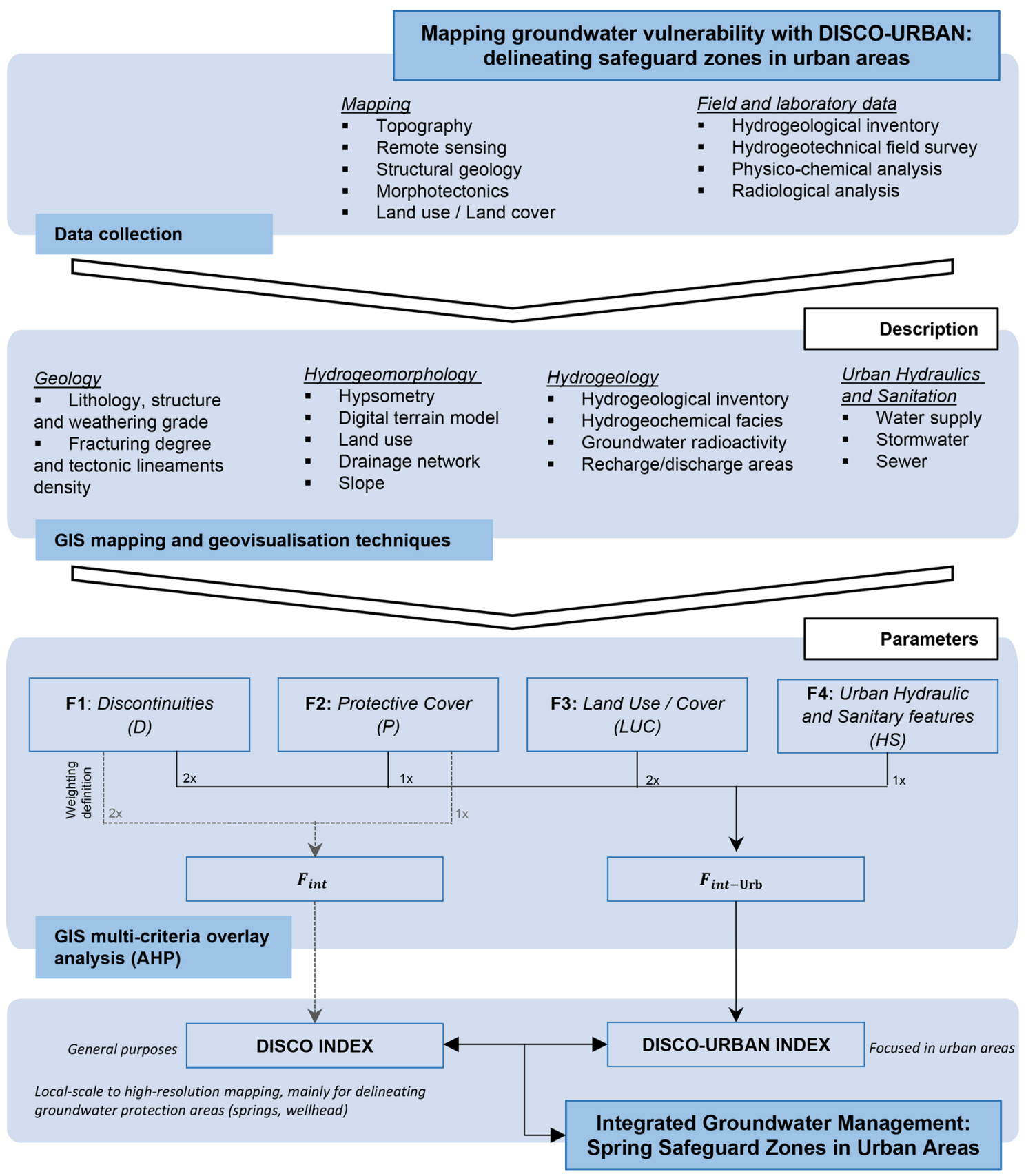

Fig. 3 Conceptual flowchart for delineating groundwater vulnerability with DISCO-URBAN index and protection safeguard zones mapping in urban areas

DISCO index takes into consideration three main parameters [30, 43, 63]: (i) hydrogeological properties of the fractured aquifer "DIScontinuities"; (ii) properties and thickness of protective Cover; (iii) runoff parameters include flow phenomena of surface water before infiltration (slope runoff, permanent or temporary flow water). It includes three main steps (details in $[43,63])$ :

\subsection{Step 1. Assessment of the discontinuities (D) and protective cover (P) parameters}

This step aims to assess and map the parameter's discontinuities and a protective cover over the entire catchment region. The discontinuities parameter $(D)$ is based on the tectonic lineaments analysis. It considers the groundwater flow velocity within the fractured aquifer between an infiltration point in the water catchment region and the springs under 


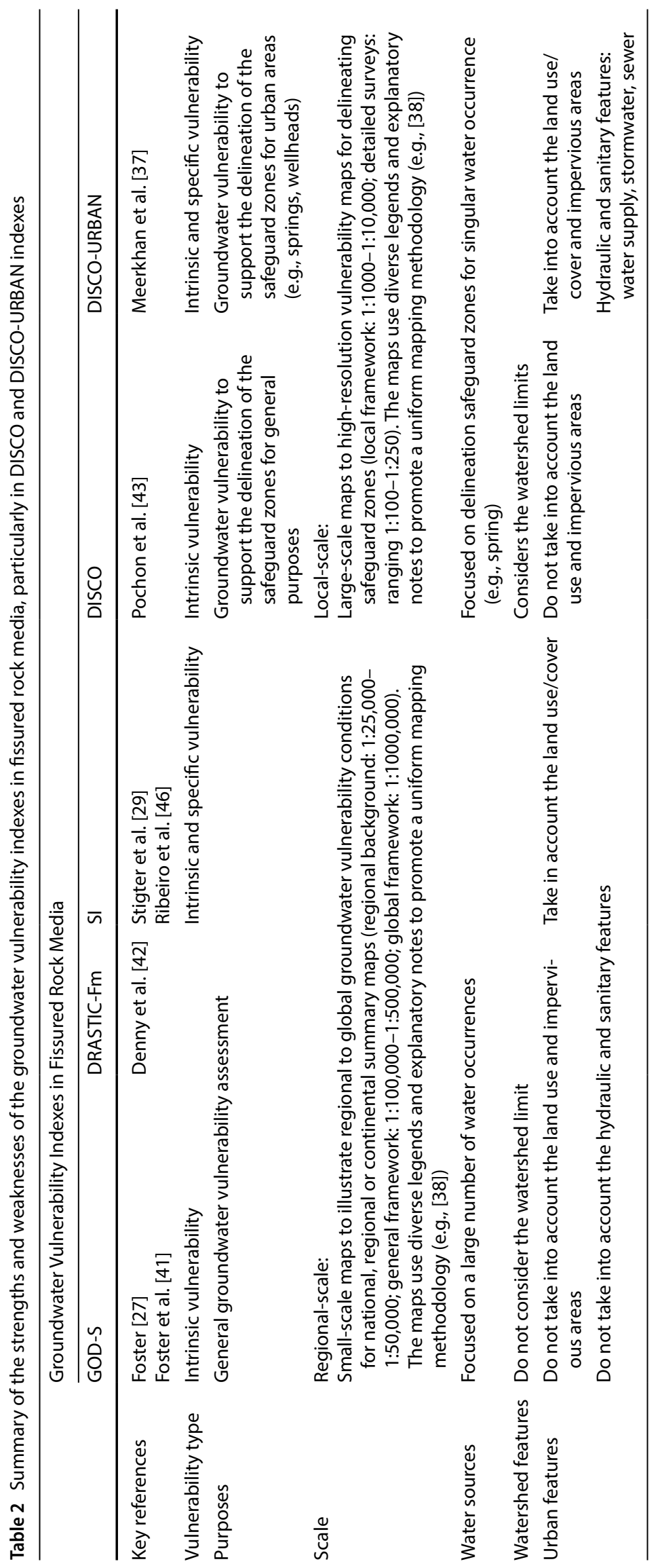


consideration. The " $\mathrm{D}$ " rating values are in the range $0-3$, with increasing values corresponding to higher residence time and attenuation processes.

The protective cover parameter $(P)$ is based on soil analysis. It considers the protective effect of water flow directly through the soil and geological formations overlying the fractured aquifer. The rating values of " $\mathrm{P}$ " are in the range $0-3$, with increasing values corresponding to each of the higher protective cover thickness and lower permeability of the deposits.

\subsection{Step 2. Determination of the intermediate protection factor $\left(F_{\text {int }}\right)$}

The protection factor $\left(\mathrm{F}_{\text {int }}\right)$ map is estimated by combining all the parameter maps, and it ranges from 1 to 9 related to the vulnerability, whereas an extremely low protection factor corresponds to a very high vulnerability. To calculate the intermediate protection factor $\left(F_{\text {int }}\right)$, the following formula was applied: $F_{\text {int }}=2 \times D+P$.

\subsection{Step 3. Protection zone delineation (F)}

According to the DISCO methodology $[43,63]$ and considering the topography's slope and the runoff area, achieving the final protection factor " $\mathrm{F}$ " is possible. Considering the watershed limits is crucial since the runoff may transport some contaminant load for the spring area. This contaminant load will be most damaging if it reaches areas of high vulnerability. Therefore, the final protection factor (F) map is converted into safeguard zones, using the inverse relationship between the value of the final protection factor " $F$ " and safeguard zones "S".

Meerkhan et al. [37] proposed that the DISCO-URBAN Index considers four main parameters. Consequently, this Index contemplates the same two parameters of the DISCO methodology: DIScontinuities " $\mathrm{D}$ " and protective Cover " $\mathrm{P}$ ", which are used in the original DISCO index and they take the same classes, and also two new parameters: Land Use/Cover parameter "LUC" and Urban hydraulics and sanitary features "HS" including water supply, stormwater and sewer networks. The general methodology and tables with weights assigned to each parameter could be found in the work of Meerkhan et al. [37]. First, GIS-based mapping was used to achieve the urban hydraulic and sanitary features by applying a line density tool considering different weights for each network: $1 \times$ water supply; $2 \times$ stormwater, and $4 \times$ sewer network. LUC ranged from 0 (high to very high) to 3 (very low to low), and HS is also in the range of 0 (very high-lower protection) to 4 (very low to null—higher protection). Next, the relative weight/score for each parameter used in the DISCO-URBAN was calculated using the analytical hierarchy process (AHP). The AHP multi-criteria technique compares all parameters, assigning a weighting to each parameter according to its importance (e.g., [64-67]). Next, a proper Consistency Ratio (CR) is calculated by dividing the Consistency Index for the set of judgments by the Index for the corresponding random matrix [65]. Saaty [64] suggests that if that ratio exceeds 0.1 , the set of judgments may be too inconsistent to be reliable. In practice, when $C R<0.1$, the consistency of the judgment matrix is acceptable; when $C R \geq 0.1$, the judgment matrix needs to be tested again (details in [65-68]).

Therefore, the understanding collected in the hydrogeological fieldwork was essential for the hierarchy of parameters. Then, the following formula was applied to calculate the urban intermediate protection factor $\left(F_{\text {int-Urb }}\right)$ : $F_{\text {int-Urb }}=2 \times D+P+2 \times L U C+H S$. Finally, the safeguard zones were computed, applying the inverse relation between the urban protection factor (F) and the safeguard zones (S). Once again, GIS technology was used to calculate these indexes and vector operations were performed using the intercept function to overlay the vector data (details of the methodology in [37].

Figure 3 presents a general methodological flowchart with the main steps of delineating groundwater vulnerability and safeguard zones mapping in urban areas and applying the DISCO and the DISCO-URBAN indexes to be effective on a local scale (urban areas). Finally, the integrative approach improves the urban hydrogeological conceptual site model in the Santa Marta springs, improving water resources management and developing environmental sustainability.

\section{Urban groundwater vulnerability assessment in Santa Marta springs: results and discussion}

Groundwater vulnerability is an intrinsic characteristic of a groundwater system that considers the hydrogeological system's sensitivity to anthropogenic interactions and natural influences. Assessing urban groundwater vulnerability to contamination to the Santa Marta groundwater system was accomplished to meet the European and Portuguese 
legislation defining strategies for determining protection zones around urban groundwater recharge areas (e.g., DecreeLaw 382/99; Decree-Law 58/2005; Ministerial Order P.702/2009). Therefore, several indexes were applied using GIS overlay techniques. By integrating and comparing these indexes' results, it will be possible to analyse the vulnerability accurately to groundwater contamination in the Santa Marta water mine (Penafiel urban area).

\subsection{Intrinsic vulnerability indexes: GOD-S, DRASTIC-Fm and SI}

The Santa Marta water mine area's intrinsic vulnerability assessment was evaluated based on GOD-S, SI, and DRASTIC-Fm indexes. Table 3 presents the synthesis of the parameters' description and the classification adopted for each method. In addition, in the supplementary materials, a synthesis of the parameters' description is presented, along with the classification adopted for the three methods (Tables S1-S3).

The GIS-based urban maps were created to assess the groundwater vulnerability to contamination in the study area. Figure 4 presents the urban groundwater vulnerability maps based on the study area's GOD-S, SI, and DRASTIC-Fm indexes. In addition, an inventory of surface potential contamination activities was surveyed over 12 potential sources (details in Table S4 in supplementary material). The potential contamination sources are located in the vicinities of the Santa Marta water mine.

The groundwater vulnerability assessment based on the GOD-S Index illustrates that most of the Santa Marta water mine area fits in a low vulnerability category. Besides the moderate vulnerability category, which is related to the alluvial deposits (Fig. 4a). The DRASTIC-Fm index, which is the updated version of the DRASTIC method, taking into account the

Table 3 Synthesis of methods for assessing vulnerability to urban groundwater contamination: GOD-S, SI and DRASTIC-Fm (details in [27, $38,39,41,42,46])$

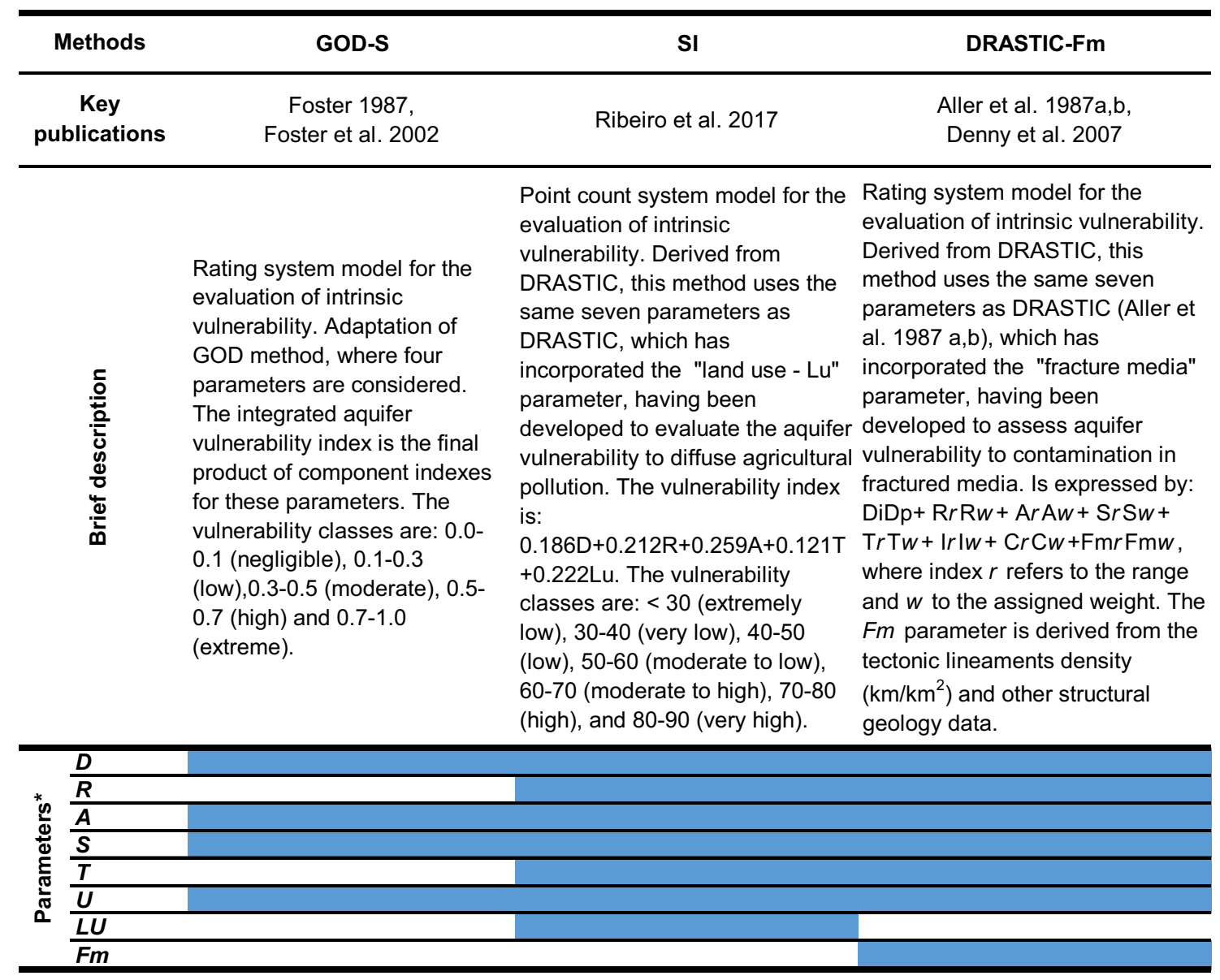

${ }^{a} D$ depth to groundwater; $R$ recharge/infiltration; $A$ aquifer characteristics (lithology, weathering grade, hydraulic conductivity, groundwater confinement, fracturing degree); $S$ soil media; $T$ topography/slope; $U$ unsaturated zone characteristics (lithology, hydraulic conductivity; $L u$ land use); Fm fracture media 
Fig. 4 Urban groundwater vulnerability assessment in the Santa Marta springs (Penafiel urban area, NW Portugal): GOD-S, DRASTICFm and $\mathrm{SI}$
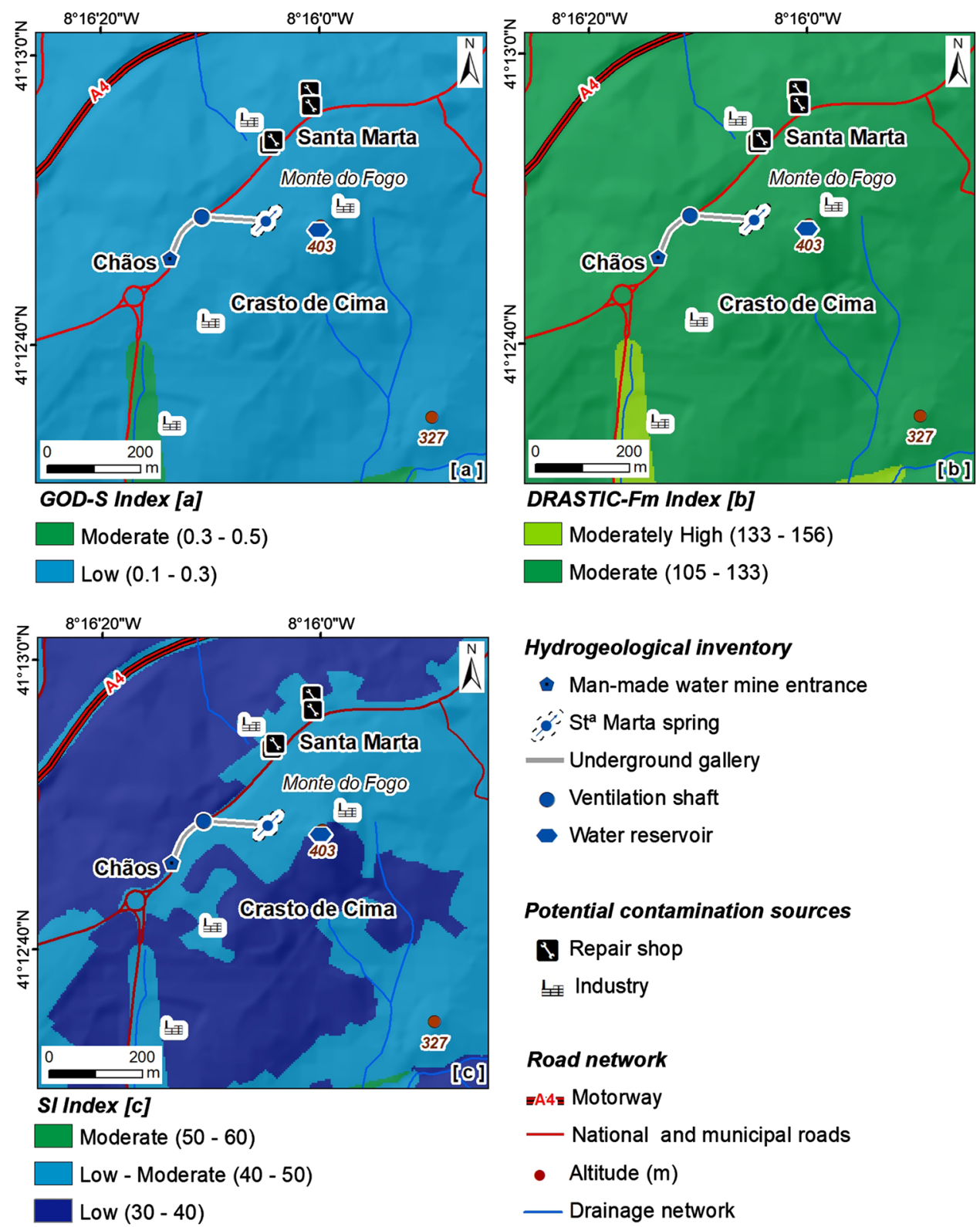

\section{Hydrogeological inventory}

- Man-made water mine entrance

'sta Marta spring

Underground gallery

- Ventilation shaft

- Water reservoir

I. Repair shop

玨 Industry

Road network

EA4= Motorway

- National and municipal roads

- Altitude (m)

_ Drainage network

\section{Potential contamination sources}

fractured media parameter, shows that the most significant space of the study area fits in a low vulnerability category. The small granitic flattened area fits low to moderate vulnerability. There is also a moderate vulnerability category related to the alluvial deposits in the DRASTIC-Fm index (Fig. 4b). Finally, the SI index indicates that most of the study area fits in the low vulnerability category, where porphyritic granite and forested areas are combined. The rest of the area fits in the low to moderate vulnerability category. In addition to the existence of a moderate vulnerability category related to alluvial deposits (Fig. 4c).

In comparing the three methods, it was recognised that the GOD-S, DRASTIC-Fm, and SI indexes indicated that Santa Marta mine water's surrounding area fits in a predominantly low to moderate vulnerability category. However, two areas should be highlighted with moderate to high vulnerability categories, corresponding to sedimentary deposits (SW and SSE of Crasto de Cima site).

\subsection{The application of DISCO and DISCO-URBAN indexes}

DISCO method allows assessing vulnerable springs' intrinsic vulnerability in highly heterogeneous fractured media, especially on a local scale [43]. This study highlights the application and the importance of the DISCO methodology in 
spring protection areas. In addition, it aims to revalidate the development of the DISCO-URBAN for local-scale investigations purposes in urban areas [37].

\subsubsection{The application of the DISCO index}

Figure 5 presents the thematic maps of the parameters used to apply the DISCO index. Figure 5 a presents the discontinuities parameter in the study area. D0 is related to the highly permeable discontinuities with preferential connection to the spring, which fits the primary tectonic lineaments in the NE-SW orientation. D1 is related to the discontinuities with a relatively connected to the spring. D2 is related to the discontinuities with a relatively slow connection to the

Fig. 5 Application of DISCO vulnerability index in Santa Marta springs (Penafiel urban area, NW Portugal): a discontinuity parameter (D); b protective cover parameter $(\mathrm{P})$; $\mathbf{c}$ intermediate protection factor $\left(F_{\text {int }}\right)$; d safeguard zones $(S)$
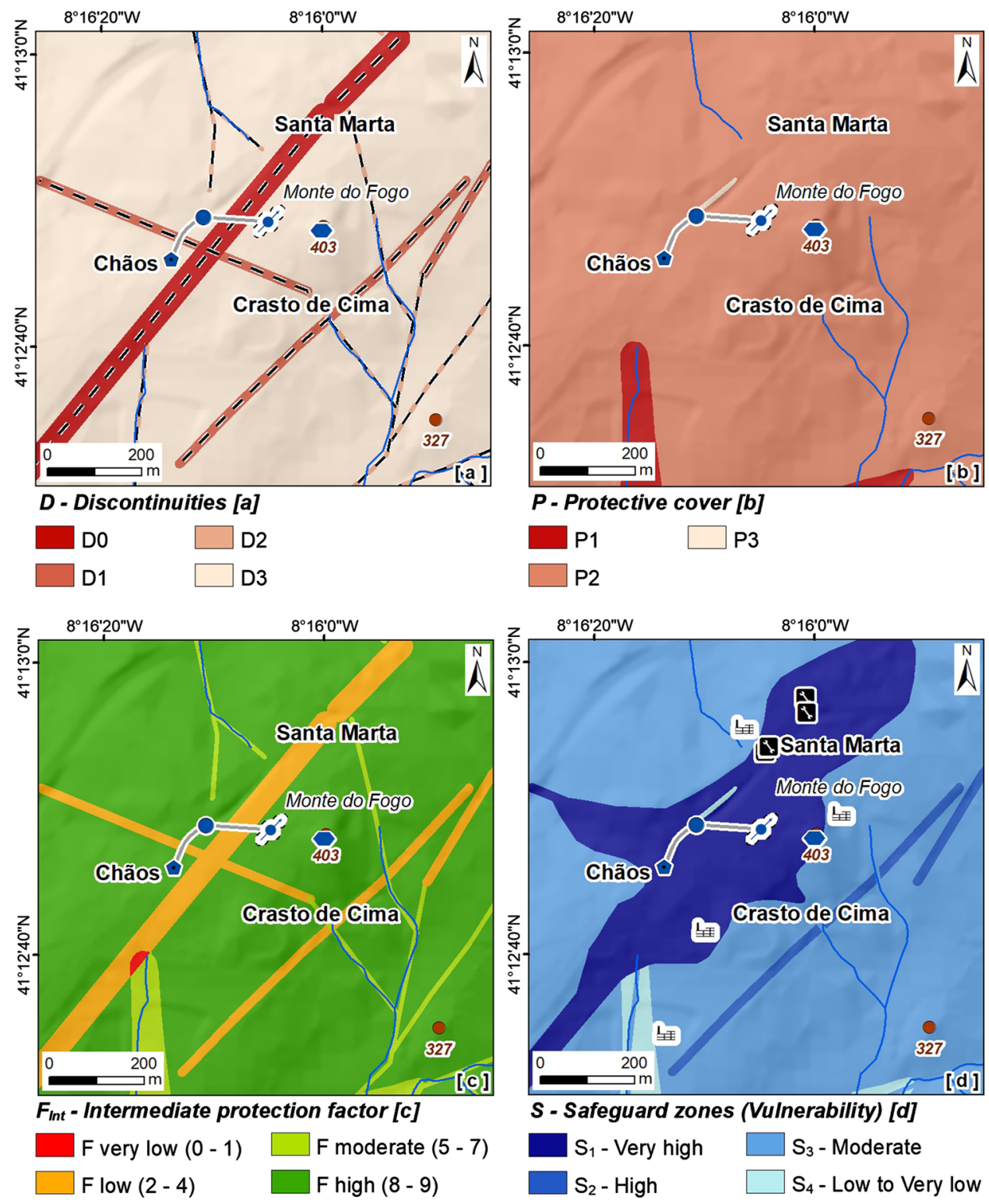

\section{Potential contamination} sources

1. Repair shop

栔 Industry

\footnotetext{
- - Tectonic lineaments

_ Drainage network

- Altitude (m)
} 
spring. Finally, D3 is related to the low permeability zone. According to the distribution of the classes (Table 4), most of the area (87\%) is characterised by low permeability, which means that the discontinuities have a slow connection to the springs. As such, purification processes are significant and occur in most studied areas. It should also be noted that in the proximity of the spring, these processes are limited due to the preferential connection between the discontinuities and the spring (D0).

Table 4 Synthesis of DISCO and DISCO-URBAN parameters results

\begin{tabular}{|c|c|c|}
\hline Methods & $\begin{array}{l}\text { DISCO } \\
\text { Pochon and Zwahlen [63]; Pochon et al. } \\
\text { [43] }\end{array}$ & $\begin{array}{l}\text { DISCO- } \\
\text { Urban } \\
\text { Meerkhan } \\
\text { et al. [37] }\end{array}$ \\
\hline Parameters & $\%$ & \\
\hline \multicolumn{3}{|l|}{ D } \\
\hline \multicolumn{3}{|l|}{ Discontinuities } \\
\hline D0 & 6.21 & \\
\hline D1 & 3.69 & \\
\hline D2 & 3.08 & \\
\hline D3 & 87.02 & \\
\hline \multicolumn{3}{|l|}{$P$} \\
\hline \multicolumn{3}{|l|}{ Protective cover } \\
\hline P1 & 2.9 & \\
\hline P2 & 96.9 & \\
\hline P3 & 0.1 & \\
\hline \multicolumn{3}{|l|}{$\begin{array}{l}\text { LUC } \\
\text { Land use/cover }\end{array}$} \\
\hline LUCO & - & 1.0 \\
\hline LUC1 & - & 33.3 \\
\hline LUC2 & - & 22.9 \\
\hline LUC3 & - & 42.8 \\
\hline \multicolumn{3}{|c|}{$\begin{array}{l}\text { HS } \\
\text { Urban hydraulics and sanitary features }\end{array}$} \\
\hline HSO & - & 2.0 \\
\hline HS1 & - & 13.4 \\
\hline HS2 & - & 67.4 \\
\hline HS3 & - & 17.3 \\
\hline \multicolumn{3}{|c|}{ Intermediate protection factor } \\
\hline \multicolumn{3}{|l|}{$F_{i n t}$} \\
\hline F very low & 0.1 & - \\
\hline F low & 9.8 & - \\
\hline F moderate & 5.4 & - \\
\hline F high & 84.7 & - \\
\hline \multicolumn{3}{|l|}{$F_{\text {int-Urb }}$} \\
\hline F very low & - & 4.8 \\
\hline Flow & - & 1.7 \\
\hline F moderate & - & 47.0 \\
\hline F high & - & 46.5 \\
\hline \multirow{2}{*}{\multicolumn{3}{|c|}{$\begin{array}{l}\text { S } \\
\text { Safeguard zones }\end{array}$}} \\
\hline & & \\
\hline S1 & 23.9 & 18.3 \\
\hline S2 & 2.4 & 2.0 \\
\hline S3 & 71.3 & 46.0 \\
\hline S4 & 2.4 & 33.7 \\
\hline
\end{tabular}

D: D0-highly permeable discontinuities with preferential connection to the spring (maximum groundwater residence time of a few tens of hours)/no significant natural purification processes; D1-discontinuities with a relatively rapid connection to the spring (residence time of a few days)/limited purification 

mately ten days)/significant purification processes; D3-low permeability zone or discontinuities with a slow connection to the spring (residence time of several tens of days)/efficient purification processes

P: P1-Moderate permeability soil (silt, loam), thickness > $1 \mathrm{~m} ; \mathrm{P} 2-$ Moderate to low permeability soil (silt, loam, clay), thickness $0.5-1 \mathrm{~m}$; P3-Low permeability soil (loam, clay), thickness $>1 \mathrm{~m}$

LUC: 0-Urban continuous; 1 -Urban discontinuous, commerce areas and roads; 2-Agricultural areas; 3-Forest areas

HS: 0-High; 1-Moderate; 2-Low, 3-Very low

According to the protective cover parameter, the study area is divided into three classes (Fig. 5b). P1 was related to moderate permeability soil, which fits the alluvial deposits unit. P2 is related to moderate to low permeability soils, consists of porphyritic granite and represents most of the study area (97\%). Finally, the P3 class was related to low permeability soil, where the crystalline bedrock is interrupted by dolerite dyke.

Figure $5 c$ presents the study area's intermediate protection factor $\left(F_{\text {int }}\right)$. Most of the study area fits the high intermediate protection factor (8-10), which can be justified by the slow connection between the discontinuities (D3) and the spring and the occurrence of soils with moderate to low permeability constituted by porphyritic granite (P2). The low intermediate protection factor (2-4) is related to the main tectonic lineaments (D0 e D1). The moderate intermediate protection factor (5-7) is related to the alluvial deposits and discontinuities with a low connection with the spring. The class with the lowest representation is the very-low intermediate protection factor, occurring due to the overlap between alluvium and discontinuities with preferential connection to the spring.

Figure $5 \mathrm{~d}$ presents the groundwater protection zones or safeguard zones that classify the study area into four classes according to the vulnerability (Table 4). $S_{1}$ zone is related to the very high vulnerability, where the main tectonic lineaments coexisted with porphyritic granite characterised for a moderate to low permeability. $S_{2}$ zone represents the high vulnerability class, and it is associated with the occurrence of secondary tectonic lineaments. $S_{3}$ zone is related to the moderate vulnerability, the most representative class in the study area, where discontinuities have a relatively slow connection to the spring (D2/D3) coexisting with the porphyritic granite a moderate to low permeability. $\mathrm{S}_{4}$ zone related to the low to very low vulnerability, which fits the alluvial deposits. Although the sedimentary deposits unit has moderate permeability, the discontinuities have no connection with the Santa Marta springs.

\subsubsection{The application of the DISCO-URBAN index}

Considering the original DISCO methodology and the used parameters, the newly DISCO-URBAN method is helpful with more accurate results in the urban contexts, especially in local-scale investigations. Furthermore, DISCO-URBAN plays an essential role in managing and protecting groundwater resources in urban environments. So, it is essential to calculate the DISCO-URBAN index to determine the parameters affecting urban groundwater vulnerability.

Figure 6 and Table 4 present the application of DISCO-URBAN in the Santa Marta water mine. Figure $6 a$, b correspond to the parameters presented and used to calculate the DISCO index. Figure $6 \mathrm{c}$ presents the Land Use/Cover parameter, which ranges between 0 and 3 classes. Class LUCO is related to the urban continuous, with an impervious surface grade high to very high. Class LUC1 is related to urban discontinuous, in which moderate to high impervious surface is observed. The rest of the study area is characterised by a low to a very low degree of imperviousness, namely those with agricultural (LUC2) and forestry (LUC3) areas. Figure $6 \mathrm{~d}$ shows the study area's urban hydraulics and sanitary features parameter (HS). It ranged from 0 (very high) to 3 (low) based on the distribution of the area's water supply, stormwater, and sewer networks. According to the HS parameter, most of the area has a moderate (HS2) to low (HS3) density (84.7\%). Figure 6e, $f$ present the urban intermediate protection factor $\left(F_{\text {int-Urb }}\right)$ and groundwater protection zones or safeguard zones in the Santa Marta water mine. Analysing the $F_{\text {int-Urb }}$ (Fig. 6e) distribution, it can be concluded that the D and LUC parameters stand out from the others. Most of the area (93.5\%) fits in the moderate to high classes. In fact, it can be observed in these areas that the coexistence between the highly permeable discontinuities with preferential connection to the spring (D0 and D1) and areas with an impervious surface grade vary from very high to low.

The groundwater protection zones or safeguard zones in the Santa Marta springs (Fig. 6e) split the area into 4 classes. The $\mathrm{S}_{1}$ class is related to the very high vulnerability and is characterised by the highly permeable discontinuities with preferential connection to the Santa Marta springs. The area in the secondary tectonic lineaments is related to the high vulnerability class $\left(\mathrm{S}_{2}\right)$. The remaining area, which fits in the agricultural and forest area without any hydraulic connection to the Santa Marta spring, is related to the moderate and low to very-low vulnerability classes $\left(S_{3}\right.$ and $\left.S_{4}\right)$. 
Fig. 6 Application of DISCOURBAN in Santa Marta springs (Penafiel urban area, NW Portugal): a discontinuity parameter (D); b protective cover parameter $(\mathrm{P})$; $\mathbf{c}$ land use/cover (LUC); d urban hydraulics and sanitary features (HS); e urban intermediate protection factor $\left(\mathrm{F}_{\text {int-Urb }}\right) ; \mathbf{f}$ safeguard zones $(\mathrm{S})$
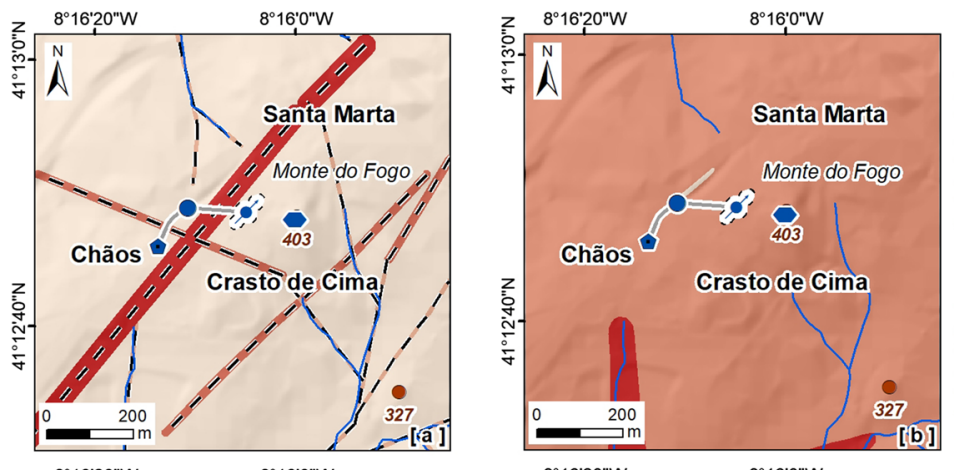

$D$ - Discontinuities [a]
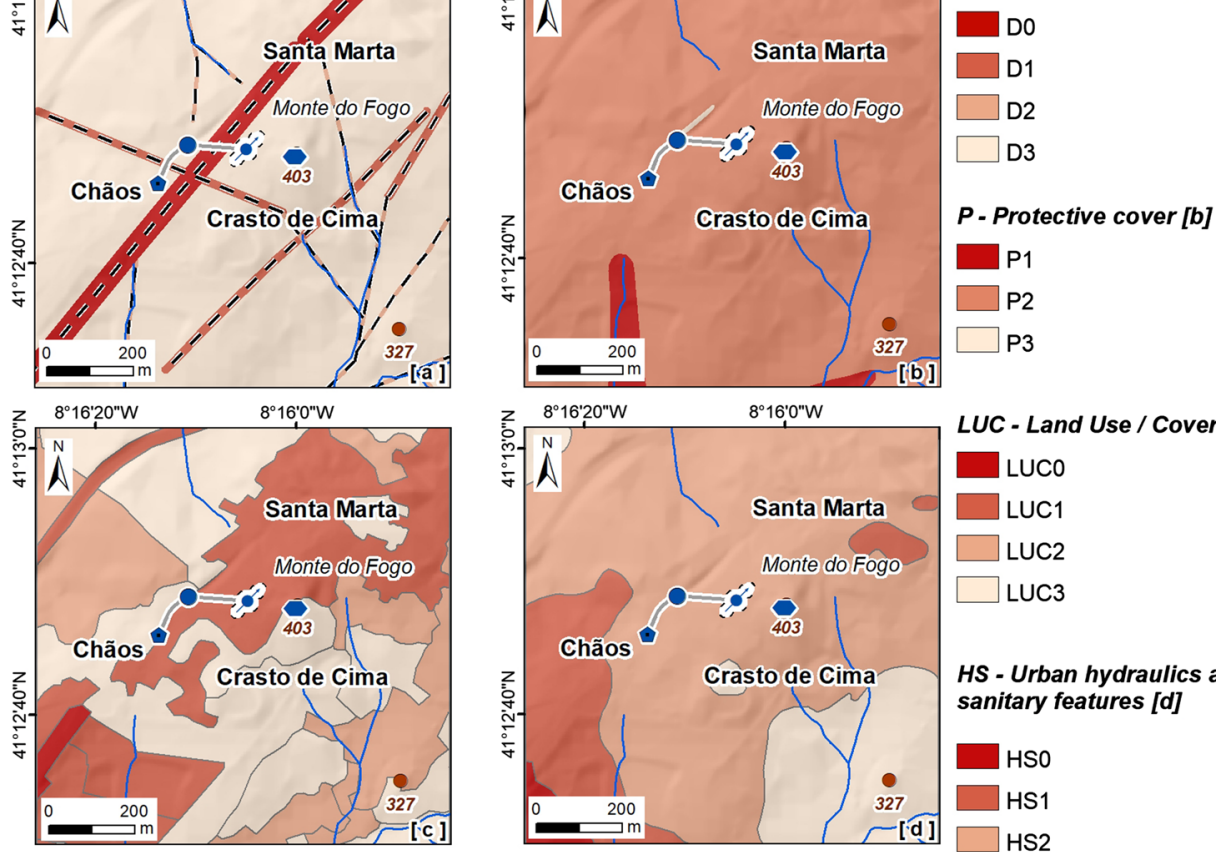

LUC - Land Use / Cover [c]

Luco

$\square$ LUC1

$\square$ LUC2

$\square$ LUC3

HS - Urban hydraulics and sanitary features [d]
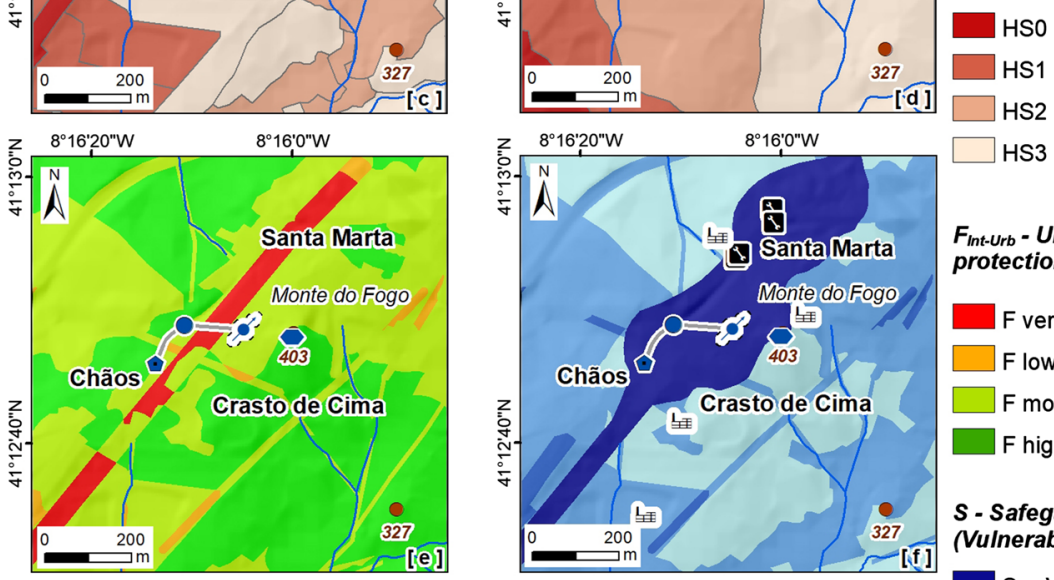

Hydrogeological inventory

Potential contamination

- Man-made water mine entrance sources
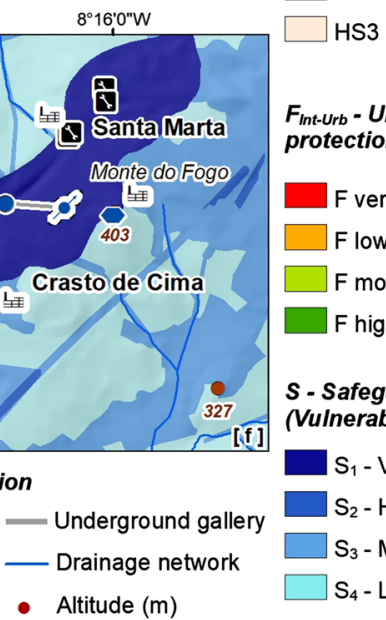

$F_{\text {Int-Urb }}$ - Urban Intermediate protection factor [e]

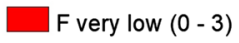

$\square$ Flow (4 - 8)

$\square \mathrm{F}$ moderate $(9$ - 14)

$F$ high (15 - 20)

S - Safeguard zones (Vulnerability) [f]

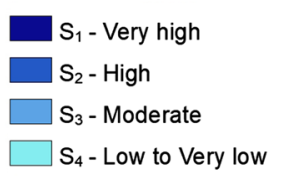

Comparing DISCO and DISCO-URBAN indexes shows that the DISCO-URBAN index results are more accurate and give more details regarding the groundwater vulnerability and protection zones. The application of the DISCO and DISCOURBAN indexes allowed us to conclude that the DISCO-URBAN index reflects more appropriately the hydrogeological conditions observed in urban areas. Table 4 highlights the most noticeable difference between DISCO and DISCO-URBAN indexes are in the S3 and S4 safeguard classes. Also, some S1 areas (very high vulnerability) were more accurately classified in DISCO-URBAN since they do not contribute to spring flow. The DISCO-URBAN methodology also allows distinguishing the S3 and S4 classes, incorporating the LUC and HS parameters.

In summary, it can be concluded that the purification process is limited or insignificant near the Santa Marta spring. Near Santa Marta spring, the area is characterised by: highly permeable discontinuities with preferential connection to the Santa Marta spring (D0), soils with moderate to low permeability, mainly constituted by porphyritic granites (P2); the land use is occupied for urban discontinuous with moderate to a high degree of imperviousness and the urban hydraulic and sanitary features have a moderate density (HS2). Given these conditions, the protection factor is low to very low, which indicates that the Santa Marta springs area has a very high $\left(\mathrm{S}_{1}\right)$ vulnerability.

The EU legislation defines a water enriched nitrate threshold of $50 \mathrm{mgL}^{-1}$ to define Nitrate Vulnerable Zones [69, 70]. Moreover, the regulation defines action programmes to reduce nitrate loss from agricultural uses, human health 
protection and water resources contamination [70]. Several works pointed out the correlation of the vulnerability indexes with contaminant parameters or land use (e.g., [71-73]). In the present study, the preliminary analytical NO3- data pointed out a value range of $65-95 \mathrm{mgL}^{-1}$ [15]. In addition, there are recorded nitrate values (lower $40 \mathrm{mgL}^{-1}$ ) in other springs in the surroundings of the study area included in the same hydrogeological unit (porphyritic granite coarse-grained, twomica). Comparing the nitrates values with the regional vulnerability mapping (GOD-S, DRASTIC-Fm, SI), the higher values match the low to moderate classes (Fig. 4). Conversely, in the local vulnerability mapping (DISCO and DISCO-URBAN), these groundwater enriched nitrates values tie in the very high vulnerability classes (Figs. 5 and 6).

Consequently, The DISCO method allows, at a local scale, a consistent evaluation to delineate groundwater vulnerability protection zones of springs and/or wellhead zones. Thus, DISCO or DISCO-URBAN methodologies' main advantage is related to the local-scale of application, i.e., it is not the best methodology for regional approaches (details in $[30,37,43]$ ). That demonstrates the applicability of the DISCO-URBAN approach underlining the local-scale to high-resolution vulnerability mapping to delineate safeguard zones (e.g., springs, wellheads) and urban groundwater management activities.

Comparing the several vulnerability indexes shows the benefit of detailed analysis, offering a better insight into intrinsic and specific vulnerability's existence and spatial distribution, as well as contributing to the site hydrogeological conceptual model [47, 74]. Saida [75] pointed out several different models to assess groundwater vulnerability, i.e., there is no universal model for groundwater vulnerability assessment. The selection of models with which the groundwater vulnerability will be assessed depends mainly on the hydrogeological settings of the natural system and data availability [75].

\section{Delineating safeguard protection zones of Santa Marta springs}

The Santa Marta water mine may constitute one of the primary sources to supply the central gardens and fountains in the urban area of Penafiel [15]. Mapping groundwater vulnerability and protection zones improved the conceptual hydrogeological site model (Fig. 7). The Santa Marta mine's recharge area is related to the flattened areas of Santa Marta, which are mainly occupied by forests. The precipitation values range between 1300 and $1350 \mathrm{~mm} /$ year, with infiltration rates of around $6 \%$. According to the DISCO-URBAN index, the Santa Marta springs is characterised by a very high vulnerability. European and Portuguese legislation defines strategies to determine the protection zones around urban springs (Decree-Law 382/99; Decree-Law 58/2005; Ministerial Order P.702/2009). Therefore, DISCO-URBAN has been proved to be a valuable tool for refining the delimitation of these areas (e.g., [37]). In the Santa Marta springs area, two types of aquifer systems were identified that are directly connected to the springs (details in [15]):

i. A superficial unconfined unit (5-10 m), corresponding to the alluvial deposits unit, a shallow water table $(<5 \mathrm{~m})$, a moderate transmissivity $\left(10-20 \mathrm{~m}^{2} / \mathrm{d}\right)$, a moderate permeability $(<4 \mathrm{~m} / \mathrm{d})$, and a $\mathrm{Na}-\mathrm{Cl}$ to $\mathrm{Na}-\mathrm{NO}_{3}$ hydrochemical facies. Thus, the vulnerability to contamination is moderate.

ii. An unconfined to confined unit, corresponding to the highly weathered to decomposed two micas granite, coarsegrained, with a thickness ranging from 0 to $20 \mathrm{~m}$, a shallow water table $(5-10 \mathrm{~m})$, a low transmissivity $\left(1.5 \mathrm{~m}^{2} / \mathrm{d}\right)$, a low permeability $(<1 \mathrm{~m} / \mathrm{d})$, and a $\mathrm{Na}-\mathrm{Cl}$ to $\mathrm{Na}-\mathrm{Cl}-\mathrm{SO}_{4}$ hydrochemical facies. Wherein the vulnerability to contamination is low to moderate.

iii. An unconfined to confined unit, corresponding to the fresh to moderately weathered two micas granite, coarsegrained, with a thickness ranging from 0 to $10 \mathrm{~m}$, a shallow water table $(5-10 \mathrm{~m})$, a very low transmissivity $(0.5-$ $\left.1.5 \mathrm{~m}^{2} / \mathrm{d}\right)$, a very low to low permeability $(<0.4 \mathrm{~m} / \mathrm{d})$, and a $\mathrm{Na}-\mathrm{Cl}$ to $\mathrm{Na}-\mathrm{Cl}-\mathrm{SO}_{4}$ hydrochemical facies. In which the vulnerability to contamination is low to moderate.

\section{Conclusions}

Evaluating groundwater vulnerability to contamination provides visual analytics and quantitative tools to help planners and decision-makers face the increasing pressure of development and residential dependency on groundwater systems. This study performs an integrative assessment of groundwater vulnerability to contamination in a local-scale urban area, namely in the surroundings of Penafiel city (NW Portugal). A multidisciplinary integrative methodology suitable for local-scale urban areas was used by combining local data from geology, hydrogeology, hydrogeomorphology, hydrogeotechnics, land cover/use and urban hydraulics. GIS-based mapping technology allows the development 

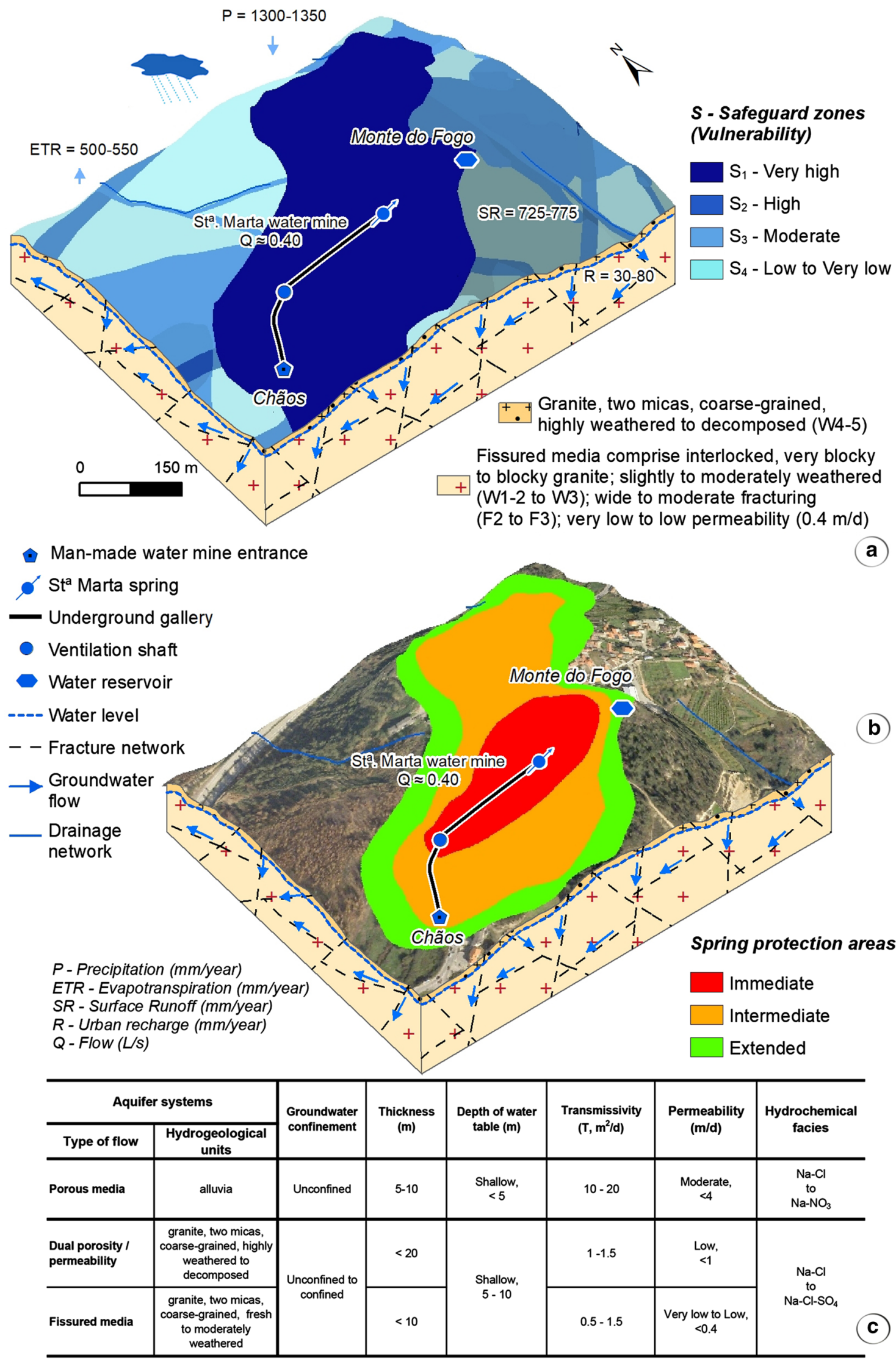

Fig. 7 Delineating vulnerability safeguard zones in Santa Marta springs (Penafiel urban area, NW Portugal) and contribution to the site hydrogeological conceptual model (hydrogeological data updated from [15]) 
of an accurate assessment of groundwater vulnerability to contamination. Furthermore, several intrinsic vulnerability indexes (e.g., GOD-S, DRASTIC-Fm, SI, DISCO and DISCO-URBAN) were applied within a combined approach to define the vulnerability safeguard zones. Understanding the source protection areas is crucial for the urban management system by supporting sustainable groundwater systems.

The combined assessment of the intrinsic vulnerability maps allows us to conclude that the study area has a low to moderate vulnerability. In addition, the DISCO and DISCO-URBAN index application enables us to delimitate the groundwater protection areas around the Santa Marta springs. The comparison between the two indexes shows that DISCO-URBAN is more accurate for urban areas since it uses some urban parameters that significantly impact groundwater quantity and quality. The study also underlines the DISCO-URBAN index as a consistent method for local-scale delineating groundwater protection areas for groundwater systems management in urban areas.

Acknowledgements This work was partially financed by FEDER-EU COMPETE Funds and the Portuguese Foundation for the Science and Technology, FCT (UID/GEO/04035/2020, UID/Multi/00611/2020), and by the Labcarga|ISEP re-equipment program (IPP-ISEP|PAD'2007/08). A doctoral scholarship to H. Meerkhan by GPSS|Foundation Casa do Regalo. FCT funded a doctoral scholarship to L. Freitas (SFRH/BD/117927/2016). Our appreciation to Penafiel municipality for their kind support in some stages of fieldwork. A special thanks to J. Teixeira, T. Abreu, and M.J. Afonso for valuable inputs. We acknowledge the anonymous reviewers and editor for their constructive comments, which helped improve the manuscript's focus.

Authors' contributions HM, LF, and HIC designed the research. HM, LF, AJSCP, FR, and HIC gave input on field surveys and inventory, urban geology and hydrogeomorphology, and GIS-based mapping of the study site and surrounding area. All authors contributed to the data analysis, interpretation and discussed results. HM, LF and HIC wrote the manuscript with the contributions of all authors. HIC and LF revised the final edited version. All authors read and approved the final manuscript.

Funding A doctoral scholarship to H. Meerkhan by GPSS|Foundation Casa do Regalo. A doctoral scholarship funded the Portuguese Foundation for Science and Technology (FCT) research to Liliana Freitas (SFRH/BD/117927/2016).

Data availability All data generated or analysed during this study are included in this article (and its supplementary information files).

\section{Declarations}

Ethics approval and consent to participate All the ethical standards of research publishing were taken care of during this study.

Competing interests The authors declare no competing interests.

Open Access This article is licensed under a Creative Commons Attribution 4.0 International License, which permits use, sharing, adaptation, distribution and reproduction in any medium or format, as long as you give appropriate credit to the original author(s) and the source, provide a link to the Creative Commons licence, and indicate if changes were made. The images or other third party material in this article are included in the article's Creative Commons licence, unless indicated otherwise in a credit line to the material. If material is not included in the article's Creative Commons licence and your intended use is not permitted by statutory regulation or exceeds the permitted use, you will need to obtain permission directly from the copyright holder. To view a copy of this licence, visit http://creativecommons.org/licenses/by/4.0/.

\section{References}

1. Barrett MH, Howard AG. Urban groundwater and sanitation: developed and developing countries. In: Howard KWF, Israfilov RG, editors. Current problems of hydrogeology in urban areas, urban agglomerates and industrial centres; NATO Science Series, IV Earth and Environmental Sciences, vol. 8. Dordrecht: Kluwer Academic Publishers; 2002. p. 39-56. https://doi.org/10.1007/978-94-010-0409-1_3.

2. Sharp JM. The impacts of urbanisation on groundwater systems and recharge. Aqua Mundi. 2010;1:51-6. https://doi.org/10.4409/ Am-004-10-0008.

3. Howard KWF. Sustainable cities and the groundwater governance challenge. Environ Earth Sci. 2015;73(6):2543-54. https://doi.org/10. 1007/s12665-014-3370-y.

4. McGrane SJ. Impacts of urbanisation on hydrological and water quality dynamics, and urban water management: a review. Hydrol Sci J. 2016;61(13):2295-311. https://doi.org/10.1080/02626667.2015.1128084.

5. Rathnayaka K, Malano H, Arora M. Assessment of sustainability of urban water supply and demand management options: a comprehensive approach. Water. 2016;8:595. https://doi.org/10.3390/w8120595.

6. IPCC. Climate Change 2021: the physical science basis. Contribution of Working Group I to the Sixth Assessment Report of the Intergovernmental Panel on Climate Change. London: Cambridge University Press; 2021.

7. Vázquez-Suñé E, Sánchez-Vila X, Carrera J. Introductory review of specific factors influencing urban groundwater, an emerging branch of hydrogeology, with reference to Barcelona, Spain. Hydrogeol J. 2005;13:522-33. https://doi.org/10.1007/s10040-004-0360-2.

8. Martínez-Navarrete C, Jiménez-Madrid A, Castaño S, Luque JA, Carrasco F. Integration of groundwater protection for human consumption in land use planning. Eur Geol J. 2013;38:53-8. 
9. Schirmer M, Leschik S, Musolff A. Current research in urban hydrogeology: a review. Adv Water Resour. 2013;51:280-91. https://doi.org/ 10.1016/j.advwatres.2012.06.015.

10. Afonso MJ, Freitas L, Pereira AJSC, Neves LJPF, Guimarães L, Guilhermino L, Mayer B, Rocha F, Marques JM, Chaminé HI. Environmental groundwater vulnerability assessment in urban water mines (Porto, NW Portugal). Water. 2016;8(11):499. https://doi.org/10.3390/w8110 499.

11. Afonso MJ, Freitas L, Chaminé HI. Groundwater recharge in urban areas (Porto, NW Portugal): the role of GIS hydrogeology mapping. Sustain Wat Resour Manag. 2019;5:203-16. https://doi.org/10.1007/s40899-019-00302-9.

12. Naves A, Samper J, Mon A, Pisani B, Montenegro L, Carvalho JM. Demonstrative actions of spring restoration and groundwater protection in rural areas of Abegondo (Galicia, Spain). Sustain Water Resour Manag. 2019;5:175-86. https://doi.org/10.1007/ s40899-017-0169-5.

13. Freitas L, Afonso MJ, Pereira AJSC, Delerue-Matos C, Chaminé HI. Assessment of sustainability of groundwater in urban areas (Porto, NW Portugal): a GIS mapping approach to evaluate vulnerability, infiltration and recharge. Environ Earth Sci. 2019;78:140. https:// doi.org/10.1007/s12665-019-8167-6.

14. Freitas L, Chaminé HI, Pereira AJSC. Coupling groundwater GIS mapping and geovisualisation techniques in urban hydrogeomorphology: focus on methodology. SN Appl Sci. 2019;1:490. https://doi.org/10.1007/s42452-019-0519-z.

15. Freitas L, Chaminé HI, Afonso MJ, Meerkhan H, Abreu T, Trigo JF, Pereira AJSC. Integrative groundwater studies in a small-scale urban area: case study from the municipality of Penafiel (NW Portugal). Geosciences. 2020;10:54. https://doi.org/10.3390/geosciences 1002 0054.

16. Wiles TJ, Sharp JM. The secondary permeability of impervious cover. Environ Eng Geosci. 2008;14(4):251-65. https://doi.org/10.2113/ gseegeosci.14.4.251.

17. Hibbs BJ. Groundwater in urban areas. J Contemp Water Res Educ. 2016;159:143. https://doi.org/10.1111/j.1936-704X.2016.03226.X.

18. Attard G, Winiarski T, Rossier Y, Eisenlohr L. Review: impact of underground structures on the flow of urban groundwater. Hydrogeol J. 2016;24:5-19. https://doi.org/10.1007/s10040-015-1317-3.

19. Sharp JM. Ground-water supply issues in urban and urbanizing areas. In: Chilton J, editor. Groundwater in the urban environment: problems, process and management. Rotterdam: A.A. Balkema; 1997. p. 67-74.

20. García-Fresca B, Sharp JM. Hydrogeologic considerations of urban development: urban-induced recharge. In: Ehlen J, Haneberg WC, Larson RA, editors. Humans as geologic agents reviews in engineering geology, vol. XVI. Boulder: The Geological Society of America; 2005. p. 123-36.

21 García-Fresca B. Urban-enhanced groundwater recharge: review and case study of Austin, Texas, USA. In: Howard KWF, editor. Urban groundwater: meeting the challenge. International Association of Hydrogeologists Selected Papers. London: Taylor \& Francis Group; 2007. p. 3-18.

22. Hibbs BJ, Sharp JM. Hydrogeological impacts of urbanisation. Environ Eng Geosci. 2012;18(1):3-24. https://doi.org/10.2113/gseegeosci. 18.1.3.

23. Foster S, Hirata R, Custodio E. Waterwells: how can we make legality more attractive? Hydrogeol J. 2021;29:1365-8. https://doi.org/10. 1007/s10040-021-02319-x.

24. Freitas L, Afonso MJ, Devy-Vareta N, Pereira AJSC, Carvalho JM, Chaminé HI. Groundwater vulnerability mapping and ancestral systems of water galleries (Porto Urban Area, NW Portugal): a design on nature-based solutions. In: Abrunhosa M, Chambel A, Peppoloni S, Chaminé $\mathrm{HI}$, editors. Advances in geoethics and groundwater management: theory and practice for a sustainable development. Advances in science, technology \& innovation. Cham: Springer; 2021. p. 493-501. https://doi.org/10.1007/978-3-030-59320-9_105.

25 Ribeiro L. Revisiting ancestral groundwater techniques as nature based solutions for managing water. In: Abrunhosa M, Chambel A, Peppoloni S, Chaminé HI, editors. Advances in geoethics and groundwater management: theory and practice for a sustainable development. Advances in science, technology \& innovation. Springer: Cham; 2021. p. 483-7. https://doi.org/10.1007/978-3-030-59320-9_103.

26. Chaminé HI, Carvalho JM, Freitas L. Sustainable groundwater management in rural communities in developed countries: some thoughts and outlook. Med Geosc Rev. 2021;3(3):389-98. https://doi.org/10.1007/s42990-021-00064-7.

27. Foster SD. Fundamental concepts in aquifer vulnerability, pollution risk and protection strategy. In: van Duijvenbooden W, van Waegeningh HG, editors. Vulnerability of soil and under groundwater to pollutants, Proceedings and Information, vol. 38. The Hague: TNO Committee on Hydrological Research; 1987. p. 69-86.

28. Vrba J, Zaporozec A. Guidebook on mapping groundwater vulnerability International contributions to hydrogeology, vol. 16. Hannover: Verlag Heinz Heise; 1994.

29. Stigter TY, Ribeiro L, Dill AM. Evaluation of an intrinsic and a specific vulnerability assessment method in comparison with groundwater salinisation and nitrate contamination levels in two agricultural regions in the south of Portugal. Hydrogeol J. 2006;14:79-99. https:// doi.org/10.1007/s10040-004-0396-3.

30. Meerkhan H, Teixeira J, Espinha Marques J, Afonso MJ, Chaminé HI. Delineating groundwater vulnerability and protection zone mapping in fractured rock masses: focus on the DISCO index. Water. 2016;8:462. https://doi.org/10.3390/w8100462.

31. Pisinaras V, Polychronis C, Gemitzi A. Intrinsic groundwater vulnerability determination at the aquifer scale: a methodology coupling travel time estimation and rating methods. Environ Earth Sci. 2016;75:85. https://doi.org/10.1007/s12665-015-4965-7.

32. Burgess DB, Fletcher SW. Methods used to delineate groundwater source protection zones in England and Wales. Geol Soc Lond Spec Publ. 1998;130:199-210. https://doi.org/10.1144/GSL.SP.1998.130.01.18.

33. Bussard T, Tacher L, Parriaux A, Maître V. Methodology for delineating groundwater protection areas against persistent contaminants. $Q$ J Eng Geol Hydrogeol. 2006;39(1):97-109. https://doi.org/10.1144/1470-9236/04-061.

34. Ettazarini S. Groundwater potentiality index: a strategically conceived tool for water research in fractured aquifers. Environ Geol. 2007;52(3):477-87. https://doi.org/10.1007/s00254-006-0481-0.

35. Goldscheider N. Delineation of spring protection zones. In: Kresic N, Stevanovic Z, editors. Groundwater hydrology of springs: engineering, theory, management, and sustainability. Butterworth-Heinemann: Oxford; 2010. p. 305-38.

36 Dottridge J, Foley A, Walters N. Safeguarding of groundwater abstractions by enforcement of source protection zones. In: Abrunhosa M, Chambel A, Peppoloni S, Chaminé HI, editors. Advances in geoethics and groundwater management: theory and practice for a sustainable 
development. Advances in science, technology and innovation. Cham: Springer; 2021. p. 515-8. https://doi.org/10.1007/978-3-030-593209_109.

37. Meerkhan H, Freitas L, Teixeira J, Rocha F, Pereira AJSC, Afonso MJ, Chaminé HI. DISCO-Urban: an updated GIS-based vulnerability mapping method for delineating groundwater protection zones in historic urban areas. Med Geosc Rev. 2021;3(3):361-77. https://doi.org/ 10.1007/s42990-021-00063-8.

38. Aller L, Bennet T, Lehr JH, Petty R, Hackett G. DRASTIC: a standardised system for evaluating groundwater pollution potential using hydrogeologic settings. US EPA Report, 600/2-87/035. Ada: Robert S. Kerr Environmental Research Laboratory, U.S. Environmental Protection Agency; 1987.

39. Aller L, Lehr JH, Petty R, Bennet T. DRASTIC: standardised system for evaluating groundwater pollution potential using hydrogeologic settings. J Geol Soc India. 1987;29(1):23-37.

40. Gogu RC, Dassargues A. Current trends and future challenges in groundwater vulnerability assessment using overlay and index methods. Environ Geol. 2000;39(6):549-59. https://doi.org/10.1007/s002540050466.

41. Foster S, Hirata R, Gomes D, Delia M, Paris M. Groundwater quality protection: a guide for water utilities, municipal authorities, and environment agencies. Washington: The International Bank for Reconstruction and Development/The World Bank; 2002.

42. Denny SC, Allen DM, Journeay M. A modified vulnerability mapping method for structurally-controlled aquifers. Hydrogeol J. 2007;15:48393. https://doi.org/10.1007/s10040-006-0102-8.

43. Pochon A, Tripet J-P, Kozel R, Meylan B, Sinreich M, Zwahlen F. Groundwater protection in fractured media: a vulnerability-based approach for delineating protection zones in Switzerland. Hydrog J. 2008;16(7):1267-81. https://doi.org/10.1007/s10040-008-0323-0.

44. Shirazi SM, Imran HM, Akib S. GIS-based DRASTIC method for groundwater vulnerability assessment. J Risk Res. 2012;15(8):991-1011. https://doi.org/10.1080/13669877.2012.686053.

45. Foster SD, Hirata R, Andreo B. The aquifer pollution vulnerability concept: aid or impediment in promoting groundwater protection? Hydrogeol J. 2013;21:1389-2139. https://doi.org/10.1007/s10040-013-1019-7.

46. Ribeiro LF, Pindo JC, Dominguez-Granda L. Assessment of groundwater vulnerability in the Daule aquifer, Ecuador, using the susceptibility index method. Sci Tot Environ. 2017;574:1674-83. https://doi.org/10.1016/j.scitotenv.2016.09.004.

47. Barbulescu A. Assessing groundwater vulnerability: DRASTIC and DRASTIC-like methods: a review. Water. 2020;12:1356. https://doi.org/ 10.3390/w12051356.

48 Witkowski A, Kowalczyk A, Vrba J. Groundwater vulnerability assessment and mapping. London: Taylor \& Francis Group; 2007.

49. Chaminé HI, Afonso MJ, Freitas L. From historical hydrogeological inventories, through GIS mapping to problem solving in urban groundwater systems. Eur Geol J. 2014;38:33-9.

50. Chaminé HI, Carvalho JM, Teixeira J, Freitas L. Role of hydrogeological mapping in groundwater practice: back to basics. Eur Geol J. 2015;40:34-42.

51. Chaminé HI, Teixeira J, Freitas L, Pires A, Silva RS, Pinho T, Monteiro R, Costa AL, Abreu T, Trigo JF. From engineering geosciences mapping towards sustainable urban planning. Eur Geol J. 2016;41:16-25.

52. Kresik N, Mikszewski A. Hydrogeological conceptual site models: data analysis and visualisation. Boca Raton: CRC Press; 2013.

53. INE—Instituto Nacional de Estatística. Informação estatística sobre a população portuguesa: Concelho de Penafiel. http://www.ine.pt/. 2021. Accessed Dec 2021.

54. Medeiros A, Pereira E, Moreira A. Carta Geológica de Portugal, na escala de 1:500,000 Folha 9-D (Penafiel). Lisboa: Serviços Geológicos de Portugal; 1981.

55. Peel MC, Finlayson BL, McMahon TA. Updated world map of the Köppen-Geiger climate classification. Hydrol Earth Syst Sci. 2007;11:163344. https://doi.org/10.5194/hess-11-1633-2007.

56. Ribeiro A, Munhá J, Dias R, Mateus A, Pereira E, Ribeiro L, Fonseca PE, Araújo A, Oliveira JT, Romão J, Chaminé HI, Coke C, Pedro J. Geodynamic evolution of the SW Europe Variscides. Tectonics. 2007;26:TC6009. https://doi.org/10.1029/2006TC002058.

57 Dykes J, Maceachren AM, Kraak M-J. Exploring geovisualization. Amsterdam: International Cartographic Association, Elsevier; 2005.

58. Kraak MJ. A cartographer, shaped by context and challenged by classics. Cartogr J. 2013;50(2):112-6. https://doi.org/10.1179/00087 $04113 Z .00000000075$.

59. DGT—Direção-Geral do Território. Especificações técnicas da carta de uso e ocupação do solo de Portugal continental para 2018. Lisboa: Direção-Geral do Território; 2019.

60. Freitas L. Avaliação integrada de recursos hídricos em áreas urbanas: aplicações para a sustentabilidade e o ordenamento territorial. Coimbra: Faculdade de Ciências e Tecnologia da Universidade de Coimbra; 2019.

61. Meerkhan H. Groundwater vulnerability in hard-rock hydrosystems: methodologies, issues and challenges. Aveiro: University of Aveiro; 2021. (on going Thesis)

62. CFCFF-Committee on Fracture Characterization and Fluid Flow. Rock fractures and fluid flow: contemporary understanding and applications. Washington DC: National Research Council, The National Academies; 1996.

63 Pochon A, Zwahlen F. Délimitation des zones de protection des eaux souterraines en milieu fissure. Technical Report. Berne: Office Fédéral de L'Environnement; 2003.

64. Saaty TL. Decision making for leaders: the analytic hierarchy process for decisions in a complex world. 3rd ed. Pittsburgh: RWS Publications; 2012.

65. Goepel KD. Implementing the analytic hierarchy process as a standard method for multi-criteria decision making in corporate enterprises: a new AHP Excel template with multiple inputs. Kuala Lumpur: Proceedings of the International Symposium on the Analytic Hierarchy Process; 2013. p. 1-10. https://doi.org/10.13033/isahp.y2013.047.

66 Brunelli M. Introduction to the analytic hierarchy process. In: SpringerBriefs in Operations Research. Berlin: Springer; 2015.

67. Mu E, Pereyra-Rojas M. Understanding the analytic hierarchy process. Cham: Springer; 2017.

68. Zhang Q, Li P, Lyu Q, Ren X, He S. Groundwater contamination risk assessment using a modified DRATICL model and pollution loading: a case study in the Guanzhong Basin of China. Chemosphere. 2022;291:132695. https://doi.org/10.1016/j.chemosphere.2021.132695.

69. OJEC-Official Journal of the European Communities. Directive 91/676/EEC of the Council Directive of 12 December 1991 concerning the protection of waters against pollution caused by nitrates from agricultural sources. Off J Eur Commun L. 1991;375:1-8. 
70. EU-European Commission. Report from the Commission. Implementation of Council Directive 91/676/EEC concerning the protection of waters against pollution caused by nitrates from agricultural sources. Synthesis from year 2000 Member States reports. EU, Brussels, COM 407. 2002. https://eurlex.europa.eu/legalcontent/EN/TXT/PDF/?uri=CELEX:52002DC0407\&from=EN. Accessed on 26 Feb 2022.

71. Rupert MG. Calibration of the DRASTIC ground water mapping method. Ground Water. 2001;39(4):625-30. https://doi.org/10.1111/j. 1745-6584.2001.tb02350.x.

72. Javadi S, Kavehkar N, Mohammadi K, Khodadadi A, Kahawita R. Calibrating DRASTIC using field measurements, sensitivity analysis and statistical methods to assess groundwater vulnerability. Water Int. 2011;36(6):719-32. https://doi.org/10.1080/02508060.2011.610921.

73. Vu T-D, Ni C-F, Li W-C, Truong M-HH. Modified index-overlay method to assess spatial-temporal variations of groundwater vulnerability and groundwater contamination risk in areas with variable activities of agriculture developments. Water. 2019;11(12):2492. https://doi. org/10.3390/w11122492.

74. Kumar P, Bansod KS, Debnath KS, Thakur PK, Ghanshyam C. Index-based groundwater vulnerability mapping models using hydrogeological settings: a critical evaluation. Environ Impact Assess Rev. 2015;51:38-49. https://doi.org/10.1016/j.eiar.2015.02.001.

75. Saida S, Tarik H, Abdellah A, Farid H, Hakim B. Assessment of groundwater vulnerability to nitrate-based on the optimised DRASTIC models in the GIS environment (Case of Sidi Rached Basin, Algeria). Geosciences. 2017;7(2):20. https://doi.org/10.3390/geosciences7020020.

Publisher's Note Springer Nature remains neutral with regard to jurisdictional claims in published maps and institutional affiliations. 